\title{
Larvae of Bembidiini (Coleoptera: Carabidae): Subtribes Tachyina and Xystosomina
}

\author{
VASILY V. GREBENNIKOV ${ }^{1,2, *}$ and DAVID R. MADDISON ${ }^{3}$ \\ ${ }^{1}$ Eastern Cereal and Oilseed Research Center, Agriculture and Agri-Food Canada, Research Branch, K.W. Neatby Building, \\ 960 Carling Avenue, Ottawa, Ontario, K1A 0C6, Canada \\ ${ }^{2}$ Department of Epidemiology, Research Institute for Plague Control, Gorkogo str. 117, Rostov-on-Don, 344007, Russia \\ ${ }^{3}$ Department of Entomology, University of Arizona, Tucson, AZ 85721, USA
}

Key words. Larvae, Coleoptera, description, Carabidae, Tachyina, Xystosomina, Mioptachys, Tachyta, Tachys, Polyderis, Elaphropus, Sphaerotachys, Paratachys, Porotachys

\begin{abstract}
Larvae of 13 species of the bembidiine subtribes Tachyina (the genera Tachyta Kirby, Tachys Dejean, Polyderis Motschulsky, Elaphropus Motschulsky, Sphaerotachys G. Müller, Paratachys Casey, Porotachys Netolitzky) and Xystosomina (the genus Mioptachys Bates) were studied. Larvae of all studied taxa are described, diagnosed and illustrated. A key to genera is provided separately for the first- and older-instar larvae. Monophyly and phylogenetic position of the subtribes and genera are discussed on the basis of presumably apomorphic character states of larvae. Based on at least six synapomorphic character states the subtribes Tachyina and Xystosomina appear to form a monophyletic group. On the other hand, there are no synapomorphies to propose a sister-group relationship between Tachyina and Xystosomina within the supertribe Trechitae.
\end{abstract}

\section{INTRODUCTION}

Among the smallest ground beetles are the minute members of the subtribe Tachyina of Bembidiini, as well as members of the subtribe Xystosomina, a group recently removed from the Tachyina (Erwin, 1994). They are rarely longer than $5 \mathrm{~mm}$, and some adults are as small as $0.7 \mathrm{~mm}$ (Erwin, 1974a). There are several hundred species within these two groups, living on the ground in saline habitats, other riparian environments, xeric areas, as well as under bark of logs, in trees, and with ants (Erwin, 1974a; Baehr, 1995).

The recent papers by Erwin (1973, 1974a, b, 1975, 1978, 1994) for Neotropical and Baehr (1986, 1987, $1989,1990,1995)$ for Australian regions demonstrate that both subtribes are extremely diverse in the shape, size, and color of adults. To date, larvae have not been as thoroughly studied. In this paper, we describe in detail the external structure of known tachyine and xystosomine larvae, as part of a long-term study of larval diversity within the carabid supertribe Trechitae.

Larvae of the subtribe Xystosomina were first described by van Emden (1942) for Mioptachys sp. and later were briefly described by Thompson (1979) for Mioptachys flavicauda (Say, 1823). Immature stages of the subtribe Tachyina are better known. Perris (1862) was the first to describe and illustrate the larva of a tachyine, Tachyta nana (Gyllenhal, 1810). Xambeau (1894) published a description of Paratachys bistriatus (Duftschmid, 1812). Larvae of "Tachyta" nietneri Bates, 1892 (= Tachys charis Andrewes, 1925) have been briefly described by Stebbing (1914). Gardner (1938) described larvae of Tachyta umbrosa (Motschulsky, 1851). Cerruti (1939) described and illustrated the larvae of Elaphropus parvulus (Dejean, 1831). In 1942 van Emden published "A key to the genera of larval Carabidae" which contained morphological information about Tachyina based on a study of Tachyta nana, Tachys sp., Elaphropus vivax (LeConte, 1848), and E. incurvus (Say, 1830). Kirk (1972) figured the head of Elaphropus anceps (LeConte, 1848). Erwin (1975) in his Tachyta revision described larvae of Tachyta nana inornata (Say, 1823). The nominotypical subspecies, Tachyta nana nana, was described by Nikitsky (1976). Some of these genera or species were included in identification keys of carabid larvae published by Sharova (1958, 1964), Larsson (1968), Thompson (1979), Arndt (1991), and Luff (1993). However, none of the descriptions are in the modern, detailed style pioneered by Goulet (1983) and Bousquet \& Goulet (1984). During the last two decades nothing new has been added to the knowledge of larval morphology of Tachyina, except for the fact that the known features of the subtribe Tachyina were described by Maddison (1993: 153) in his review of the subgenus Bracteon Bedel, 1879 of the genus Bembidion Latreille, 1802.

In the present article we provide descriptions, diagnoses and illustrations of reared larvae of the bembidiine subtribes Tachyina and Xystosomina belonging to eight genera and 13 species. Also, we offer keys for first- and older-instar larvae to all genera studied. Finally, we discuss phylogenetic aspects of the studied taxa on the basis of shared larval apomorphies.

\footnotetext{
* Present address: Department of Zoology and Entomology, Faculty of Natural and Agricultural Sciences, University of Pretoria, 0002 Pretoria, South Africa.
} 


\section{MATERIAL AND METHODS}

This work is based on the study of 73 slide-mounted larvae of Tachyina and Xystosomina belonging to eight genera and 13 species. 125 more specimens were available in alcohol and briefly compared under low magnifications. Larvae of the following taxa have been studied: Subtribe Xystosomina: genus Mioptachys Bates, 1882 [M. flavicauda (Say, 1823), L ${ }_{1}$. Subtribe Tachyina: genera Tachyta Kirby, 1837 [T. nana (Gyllenhal, 1810), $\mathrm{L}_{1}-\mathrm{L}_{3}$ ], Tachys Dejean, 1821 (T. scutellaris (Stephens, 1829), $\mathrm{L}_{1}, \mathrm{~L}_{2} ;$ T. vittatus Motschulsky, $1850, \mathrm{~L}_{1}, \mathrm{~L}_{2}$; $T$. halophilus Lindroth, 1966, $\mathrm{L}_{1} ; T$. centriustatus (Reitter, 1874), $\left.\mathrm{L}_{1}-\mathrm{L}_{3}\right]$, Polyderis Motschulsky, 1862 [P. ?rufotestacea (Hayward, 1900), L $;$ P. laevis (Say, 1823), L 2 , Elaphropus Motschulsky, 1839 [E. diabrachys (Kolenati, 1845), $\mathrm{L}_{1}-\mathrm{L}_{3} ; E$. tripunctatus (Say, 1830), L $]$, Sphaerotachys G. Müller, 1926 [S. haemorrhoidalis (Ponza, 1805), $\left.\mathrm{L}_{1}-\mathrm{L}_{3}\right]$, Paratachys Casey, 1918 $\left[P\right.$. bistriatus (Duftschmid, 1812), $\left.\mathrm{L}_{1}-\mathrm{L}_{3}\right]$ and Porotachys Netolitzky, 1914 [P. bisulcatus (Nicolai, 1822), $\left.\mathrm{L}_{1}-\mathrm{L}_{3}\right]$. All of them were reared ex ovo from mature females kept in the laboratory. Adults were collected in Russia, Turkmenia, Canada, and the United States. Most larvae are deposited in the authors' collections (VVG and DRM); part of the material is kept in the British Museum of Natural History, London, UK (BMNH) and the Canadian National Collection, Ottawa, Canada (CNCI).

Larvae were mounted on microscope slides in Hoyer's medium and studied with a compound microscope MBI-1 at magnifications up to $900 \times$. Morphological drawings were prepared using Reichert camera lucida. The notation of sensilla in first-instar larvae follows Bousquet \& Goulet (1984), that in older-instar larvae follows Bousquet (1985), that on hypopharynx follows Makarov (1996). The term "egg-bursters" for frontal structures in first-instar larvae is used to distinguish symmetrical lines of large spines in Mioptachys and Tachyta larvae (Figs 3, 4) from groups of microscopically small spines in remaining larvae (Figs 5-11) which are referred as "microspines". All measurements have been made using a micrometre. The following abbreviations are used: HW maximum width of head; $\mathrm{HL}$ - length of head along midline; $\mathrm{L}_{1}$, $\mathrm{L}_{2}$, and $\mathrm{L}_{3}$ - first, second, and third instar respectively.

Because of limited larval material of the subtribe Xystosomina available for study (only two first-instar larvae of a single species, Mioptachys flavicauda, were studied), we are unable to provide a separate diagnosis and description for this group and clearly distinguish it from the subtribe Tachyina. Therefore, we provide a diagnosis and description of Tachyina + Xystosomina larvae combined and compare them with those of the remaining Trechitae groups known to us as larvae: Trechini (genera Perileptus Schaum, 1860, Thalassophilus Wollaston, 1854, Amblystogenium Enderlein, 1905, Trechus Clairville, 1806, Epaphius Stephens, 1827, Aepopsis Jeannel, 1922 and Trechimorphus Jeannel, 1927); Bembidiini (the subtribe Bembidiina: genera Bembidion Latreille, 1802, Asaphidion Des Gozis, 1886, Ocys Stephens, 1829, and Phrypeus Casey, 1924); Pogonini (genera Pogonus Dejean, 1821, Pogonistes Chaudoir, 1870, Cardiaderus Dejean, 1829, and Thalassotrechus Van Dyke, 1918); and Zolini (genera Oopterus Guérin-Méneville, 1841, and Idacarabus Lea, 1910).

\section{SUBTRIBES TACHYINA AND XYSTOSOMINA}

Diagnosis. First-instar larvae of Tachyina and Xystosomina differ from those of other taxa of the supertribe Trechitae by the very short or absent coronal suture (Figs 3-11); if present, its length is less than half the width of the proximal antennomere. Second- and third-instar

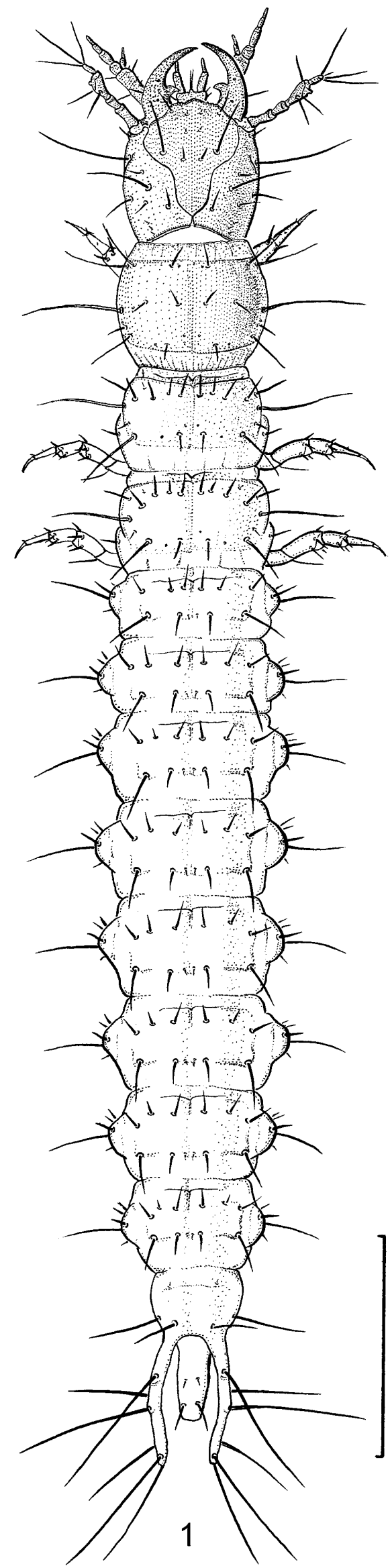

Fig. 1. Third-instar larva of Tachyta nana, habitus, dorsal view. Scale bar: $0.8 \mathrm{~mm}$. 
larvae are unique within all known Trechitae larvae by having six long setae on the urogomphi (Figs 57-60) instead of seven or, rarely, more.

\section{Description}

Width of cephalic capsule in $\mathrm{L}_{1}$ varies from 0.18 to $0.29 \mathrm{~mm}$, in $\mathrm{L}_{2}$ from 0.28 to $0.42 \mathrm{~mm}$, in $\mathrm{L}_{3}$ from 0.40 to $0.58 \mathrm{~mm}$. Body white with lightly sclerotized sclerites (Figs 1, 2, 61).

First-instar larvae. Cephalic capsule without neckconstriction in basal part (Figs 3-11); stemmata absent or, rarely, one or 2 of them present in anterior row (Figs 3-11); dorsal surface of cephalic capsule without ocular and cervical grooves (Figs 3-11); coronal suture very short or absent, if present, shorter than 0.5 width of proximal antennomere (Figs 3-11); nasale moderately produced and denticulate, with 2 rows of teeth (Figs 22, $23,25,27,29,31,33,34,36,38)$. Egg-bursters on frontale present (Figs 3-4) or absent (Figs 5-11). Microspines on cephalic capsule absent (Figs 3-4) or present on frontale near $\mathrm{FR}_{\mathrm{b}}$ as well as at base of frontale, and on parietale laterad of setae $\mathrm{PA}_{3}$ and $\mathrm{PA}_{5}$ (Figs 5-11). Antenna about as long as mandible (Figs 3-11); antennomere III with large sensorium, 2 campaniform and one placoid sensilla (Figs 12-17); antennomere IV distad with two conical and one campaniform sensilla (Figs 12-17); lateral side of antennomere III between sensorium and base of antennomere IV not sclerotized (Figs 12-17). Mandible with penicillum and retinaculum present (Figs 3-11); penicillum consists of more than 5 setae (Figs 3-11, 19); cutting edge of retinaculum smooth, not serrate (Figs 3-11, 19); cutting edge of terebra smooth (Figs 3-8, 19) or serrate (Figs 9-11); dorsal surface between pore $\mathrm{MN}_{\mathrm{b}}$ and seta $\mathrm{MN}_{1}$ with (Figs 5-11,19) or without (Figs 3-4) microspines. Maxilla without lacinia (Figs 40-45); stipes about 2.0-2.7× longer than wide (Figs 40-45); galeomere 2 about 3-5× longer than first (Figs 40-45); stipes with one or more teeth at base mediad (Figs 40-45); distal palpomere 4 not or partly subdivided (Figs 40-45). Labium with ligula (Figs 40-45); second palpomere not or partly subdivided, about as long as first (Figs 40-45). Leg with single claw (Fig. 21); coxa with some microspines dorsad. Urogomphi fixed, rather long, not joined, without nodules (Figs 57-60).

Chaetotaxy. Typical for carabids (see Bousquet \& Goulet, 1984). All primary sensilla present (except seta $\mathrm{LA}_{5}$ on labium, pores $\mathrm{PR}_{c}, \mathrm{PR}_{\mathrm{e}}, \mathrm{PR}_{\mathrm{i}}, \mathrm{PR}_{\mathrm{j}}$ and in some taxa also $\mathrm{PR}_{\mathrm{h}}$ on protergum, pores $\mathrm{ME}_{\mathrm{d}}, \mathrm{ME}_{\mathrm{e}}$ on meso- and metaterga, seta $\mathrm{ES}_{1}$ on metathorax, pore $\mathrm{TE}_{\mathrm{b}}$ on abdominal terga $1-8$, setae $\mathrm{TA}_{3}, \mathrm{TA}_{4}, \mathrm{TA}_{5}$, and $\mathrm{TA}_{6}$ on tarsus and, in some taxa, pore $\mathrm{PA}_{\mathrm{b}}$ on parietale); no additional sensilla present. Sensilla $\mathrm{EM}_{1}$ on all thoracic segments, $\mathrm{ES}_{1}$ on mesothorax, and $\mathrm{EP}_{1}$ on ninth abdominal segment present as pore-like structures. Anterior angles of hypopharynx with single seta $\mathrm{CI}_{1}$ (see Makarov, 1996) on each side. Seta $\mathrm{FR}_{6}$ removed mediad and distance between $\mathrm{FR}_{6}-\mathrm{FR}_{\mathrm{c}}$ subequal to that $\mathrm{FR}_{\mathrm{c}}-\mathrm{FR}_{4}$ (Figs 3-11); position of setae $\mathrm{FR}_{2}$ and $\mathrm{FR}_{4}$ as in generalised type (see Bousquet \& Goulet, 1984). Setal group gMX with 4-6 (usually 5) setae (Figs 40-45); seta $\mathrm{MX}_{7}$ no longer than

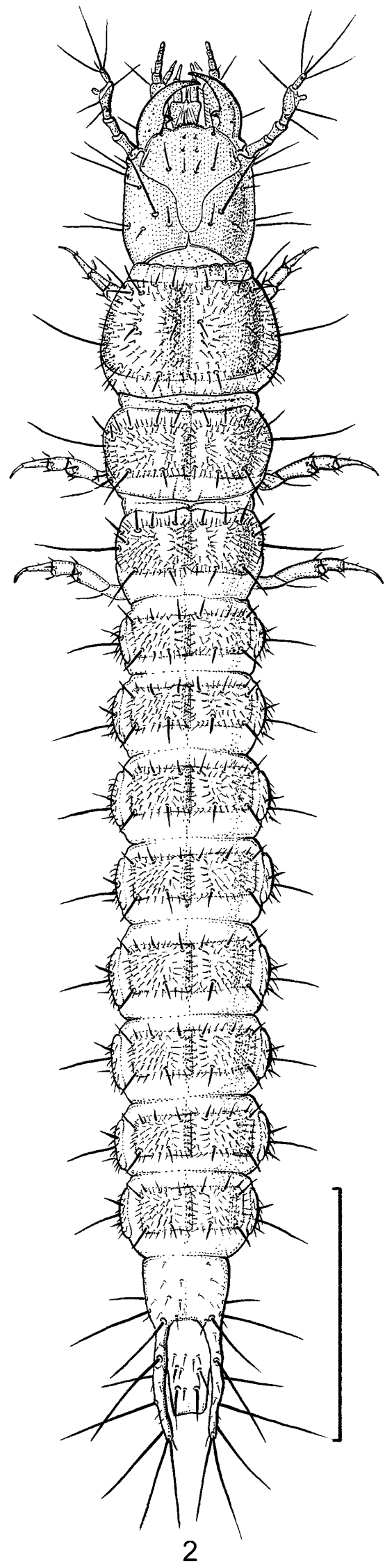

Fig. 2. Third-instar larva of Tachys centriustatus, habitus, dorsal view. Scale bar: $0.8 \mathrm{~mm}$. 


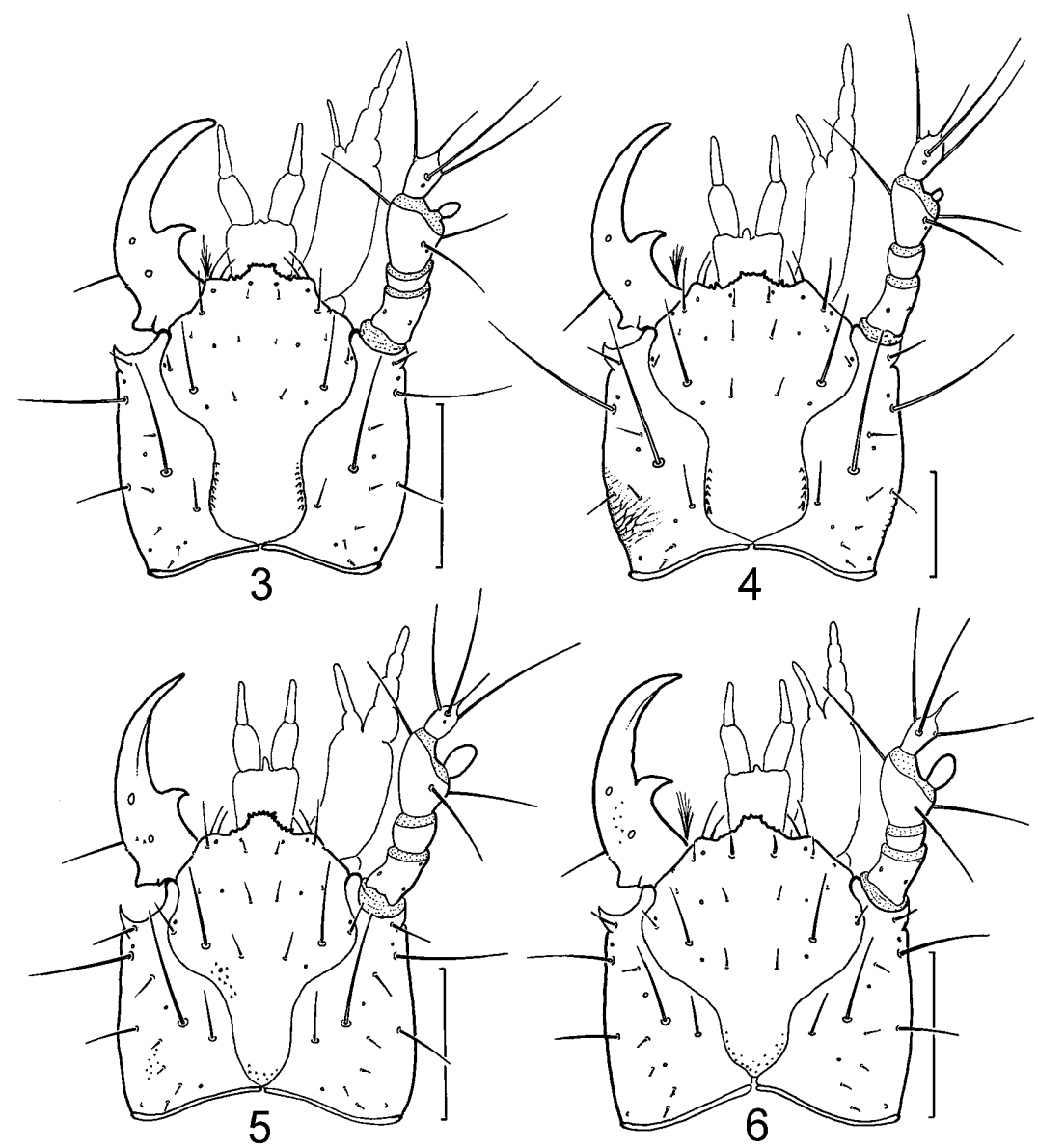

Figs 3-6: First-instar larvae of Tachyina and Xystosomina, cephalic capsule, right antenna and left mandible, dorsal view. 3 Mioptachys flavicauda; 4 - Tachyta nana; 5 - Tachys scutellaris; 6 - Polyderis ?rufotestacea. Scale bars: $0.1 \mathrm{~mm}$.

width of first maxillary galeomere; seta $\mathrm{MX}_{8}$ located at base of second maxillary galeomere; setae $\mathrm{MX}_{11}$ and $\mathrm{MX}_{12}$ shorter than $1 / 4$ of width of third maxillary palpomere. Seta $\mathrm{LA}_{6}$ on ligula trichoid. Setae $\mathrm{TI}_{2}, \mathrm{TI}_{3}, \mathrm{TI}_{4}$ on tibia normal, not modified as long and thin setae. Seta $\mathrm{UR}_{3}$ on urogomphi located near $\mathrm{UR}_{2}$ (as on Figs 57-60).

Second- and third-instar larvae. Length of coronal suture about $0.5-1.0 \times$ that of proximal antennomere (Figs 49-56); dorsal surface of cephalic capsule without ocular (except Tachyta, Fig. 49) and cervical grooves (Figs 50-56). Mandible without microspines on dorsal surface (Figs 49-56).

Chaetotaxy. Antenna and mandible without secondary setae (Figs 49-56). Group gMX with 6 (rarely 5) setae (Figs 46-48); lateral sides of stipes and labium with one secondary seta (Figs 46-48). Sensilla $\mathrm{EM}_{1}$ on prothorax, $\mathrm{EM}_{1}$ and $\mathrm{ES}_{1}$ on mesothorax, $\mathrm{EM}_{1}$ on metathorax, and $\mathrm{EP}_{1}$ on abdominal segment IX normal, trichoid-like; anterior ventrites on meso-, metathorax, and all abdominal segments with 1-7 (usually 4-6) pore-like secondary structures. Legs without secondary setae. Tergum IX with secondary seta UR alpha; its lateral side with secondary seta at middle (Figs 50-56) or, in Tachyta, without (Fig. 49); urogomphus with 6 long setae $\left(\mathrm{UR}_{4}-\mathrm{UR}_{8}\right.$, UR delta) as on Figs 57-60.

\section{Monophyly and phylogenetic relationship}

Larval features of Tachyina and Xystosomina support their inclusion into the supertribe Trechitae. Larvae of these groups share with those of the remaining Trechitae groups the absence of pores $\mathrm{PR}_{\mathrm{c}}, \mathrm{PR}_{\mathrm{e}}, \mathrm{PR}_{\mathrm{i}}, \mathrm{PR}_{\mathrm{j}}$ on protergum, pores $\mathrm{ME}_{\mathrm{d}}, \mathrm{ME}_{\mathrm{e}}$ on meso- and metaterga, seta $\mathrm{ES}_{1}$ on metathorax, pore $\mathrm{TE}_{\mathrm{b}}$ on abdominal terga $1-8$, and setae $\mathrm{TA}_{3}, \mathrm{TA}_{4}, \mathrm{TA}_{5}, \mathrm{TA}_{6}$ on tarsus. These structures are part of the ground plan of the family Carabidae (Bousquet \& Goulet, 1984) and their absence in Trechitae larvae is very likely an apomorphic condition.

To determine the relationships of tachyine and xystosomine species to other trechites, we needed to determine which of the larval features observed are apomorphic. To do this, we chose as an outgroup, and thus as an indicator of the plesiomorphic condition, the supertribe Patrobitae. Based upon adult and larval structure, cytogenetic characteristics, and molecular data (reviewed in Maddison et al., 1999), patrobites are the sister group to Trechitae.

Larval features suggest that the subtribes Tachyina + Xystosomina may represent a monophyletic group. The known larvae possess 10 character states which were never, or rarely, discovered for larvae of other Trechitae taxa and most of them are likely apomorphic within the supertribe. 
Four of these character states provide weak evidence of the monophyly of Tachyina + Xystosomina. The presence of six long setae on urogomphi in second and third instar in Tachyina + Xystosomina larvae (character 01), instead of seven in the remaining Trechitae groups (or nine and more in some species of the bembidiine subgenus Bracteon, see Maddison, 1993: 279), appears to be a character state of uncertain phylogenetic value, since larvae of Patrobitae, the taxon chosen as an outgroup, have both six and seven long setae on urogomphi in older instars (Luff, 1993: 79; Zamotajlov, 1994; Bousquet \& Grebennikov, 1999). Three other apomorphic character states of tachyines and xystosomines, not found in the outgroup, are also present in a few other trechites. While we consider these states in other trechites to be convergent (as discussed below), their existence weakens the evidence they provide for the monophyly of Tachyina + Xystosomina. These three states are: (02) Group gMX consists of no more than 6 (usually 5) setae. A similar number of setae in first-instar larvae had been noted in the genera Perileptus and Thalassophilus of the tribe Trechini (Grebennikov, 1996; Grebennikov \& Luff, 1998). (03) First-instar larvae with sensilla $\mathrm{EM}_{1}$ on prothorax, $\mathrm{EM}_{1}$ and $\mathrm{ES}_{1}$ on mesothorax, $\mathrm{EM}_{1}$ on metathorax, and $\mathrm{EP}_{1}$ on ninth abdominal segment modified as pore-like structures, instead of being trichoid setae. Similar modifications of some of these setae were noted for species of the trechine genera Epaphius, Perileptus and Thalassophilus (unpublished). (04) Second- and third-instar larvae with 1-7 (usually 4-6) secondary pore-like structures on anterior ventrites on meso-, metathorax, and all abdominal segments. A similar character state was found in Perileptus larvae (Grebennikov \& Luff, unpubl.). Characters 02-04 alone might suggest that Perileptus is the sister to Tachyina + Xystosomina, with Thalassophilus as their sister, and then with Epaphius as the sister to these four groups combined. However, other larval characteristics indicate that Epaphius is a member of Trechina (based on three synapomorphies), that Perileptus and Thalassophilus are sister groups (with three synapomorphies), and that Tachyina + Xystosomina belong to a clade including all trechites except Perileptus and Thalassophilus (this clade is united by the derived presence of only one larval claw) (Grebennikov, unpubl.). Thus it is more parsimonious to presume that character states $02-04$ are derived characteristics of Tachyina + Xystosomina, convergent to the states found in the unrelated to them genera Perileptus, Thalassophilus, or Epaphius.

Six other traits of Tachyina + Xystosomina provide compelling evidence for monophyly of that group. These states are unique within Trechitae and are not found in the outgroup Patrobitae, and thus they are clear synapomorphies of Tachyina + Xystosomina. These character states are as follows: (05) Seta $\mathrm{FR}_{6}$ on frontale is removed mediad instead of being located near lateral margin of frontale, as is shown in generalized larval chaetotaxy by Bousquet \& Goulet (1984). (06) Seta $\mathrm{LA}_{5}$ on ligula is absent. (07) Stipes with one or more teeth at base. (08) Coronal suture in first-instar larvae is very short or absent. (09) First-instar larvae with some microspines on dorsal surface of coxa, instead of being smooth. (10) Second- and third-instar larvae with only one secondary seta on lateral sides of stipes and labium, and mandibles without secondary setae. The plesiomorphic condition for trechites is more than one (usually two or more) secondary seta on each lateral side of stipes and labium, and with at least one secondary seta on mandible.

On the other hand, we were unable to find synapomorphic character states that indicate the sister group of Tachyina and Xystosomina combined. Studied larvae exhibit only a few similarities with those of some (but not all) members of the tribe Trechini, which have been noted above, but these similarities are considered convergent. Tachyine and xystosomine larvae do not show clear apomorphies with members of Bembidiina, the subtribe to which they are most often associated as members of the tribe Bembidiini. The distinctiveness of Tachyina + Xystosomina larvae, and their lack of clear relationship with other taxa, including bembidiines, provides some evidence that they could be regarded as a separate tribe Tachyini, consistent with the views of Kryzhanovskij (1983: 236). The tribe Tachyini (sensu Kryzhanovskij) includes also two more subtribes Anillina and Lymnastina, larvae of which are still unknown. Erwin (1982) considers Anillina and Lymnastina as highly derived Tachyina, not as separate clades. The question about the sister group of Tachyina + Xystosomina will not be resolved until larvae of Lymnastina, Anillina, and more taxa of Bembidiina and other Trechitae are described.

\section{KEY TO LARVAE OF THE SUBTRIBES TACHYINA AND XYSTOSOMINA}

\section{Key to larval instars}

1 Lateral side of stipes with two setae; abdominal hypopleurites without setae; urogomphi with five long setae first-instar larva

- Lateral side of stipes with three setae; abdominal hypopleurites with one or more setae; urogomphi with six long setae $\ldots \ldots \ldots \ldots \ldots . . \ldots$ second- or third-instar larva

\section{Key to genera of first-instar Tachyina and Xystosomina larvae}

1 Egg-bursters on frontale consisting of two longitudinal rows of teeth along frontal sutures (Figs 3, 4); frontale without spot of microspines; mandible on dorsal surface near pore $\mathrm{MN}_{\mathrm{b}}$ smooth, without microspines (Figs 3, 4); cephalic capsule laterally rounded (Figs 3,4) $\ldots \ldots \ldots \ldots \ldots \ldots 2$

- Egg-bursters on frontale absent (Figs 5-11); frontale with spot of microspines proximally; mandible on dorsal surface near pore $\mathrm{MN}_{\mathrm{b}}$ with microspines (Figs 5-11); cephalic capsule with parallel lateral sides (Figs $5-11$ ) ........ 3

2 Parietale near seta $\mathrm{PA}_{6}$ with meshed microsculpture (Fig. 4); distal seta of group gMX on stipes situated proximad of level of seta $\mathrm{MX}_{5}$ (Fig. 41) . . . . . . Tachyta Kirby, 1837

- Parietale near seta PA6 smooth, without meshed microsculpture (Fig. 3); distal seta of group gMX on stipes situated distad of level of seta $\mathrm{MX}_{5}$ (Fig. 40) $\ldots \ldots \ldots \ldots \ldots \ldots$

Mioptachys Bates, 1882

3 Mandible with teeth on terebra (Figs 9-11) ........4

- Mandible without teeth on terebra (Figs 5-8) ...... 6 


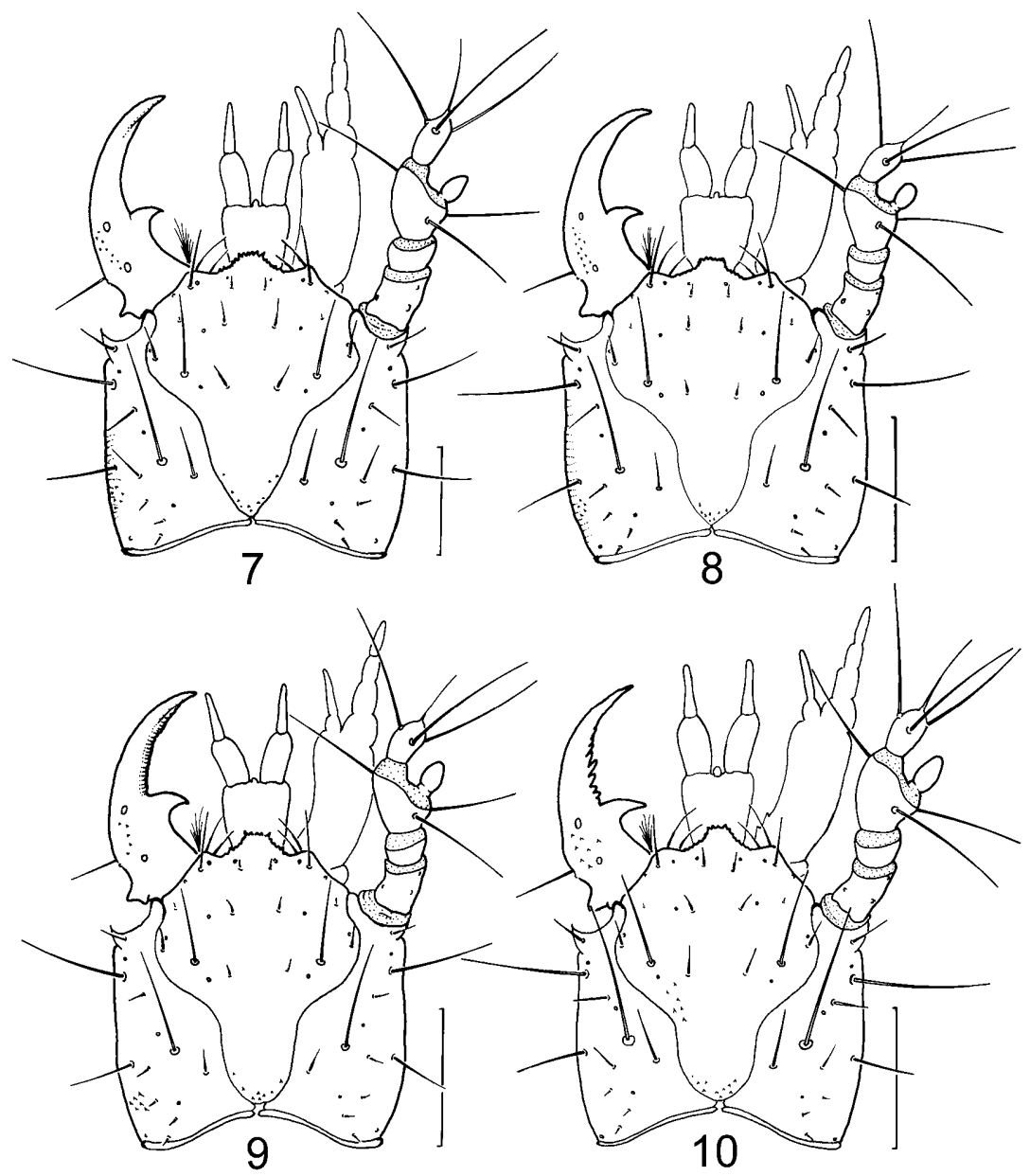

Figs 7-10: First-instar larvae of Tachyina, cephalic capsule, right antenna and left mandible, dorsal view. 7 - Elaphropus diabrachys; 8 - Elaphropus tripunctatus; 9 - Sphaerotachys haemorrhoidalis; 10 - Paratachys bistriatus. Scale bars: $0.1 \mathrm{~mm}$.

4 Terebra with about 10 small and similar teeth (Fig. 9); frontale near pore $\mathrm{FR}_{\mathrm{b}}$ smooth, without microspines (Fig. 9) Sphaerotachys G. Müller, 1926

- Terebra with 3-5 large teeth in proximal half and some small teeth distally (Figs $10-11$ ); frontale near pore $F_{\mathrm{b}}$ with microspines (Figs $10-11$ ) $\ldots \ldots \ldots \ldots \ldots \ldots$. 5

5 Parietale laterad of seta $\mathrm{PA}_{3}$ with microspines (Fig. 11); pore $\mathrm{PA}_{\mathrm{a}}$ located at level of seta $\mathrm{PA}_{1}$ (Fig. 11) $\ldots \ldots \ldots$.

.................. Porotachys Netolitzky, 1914

- Parietale laterad of seta $\mathrm{PA}_{3}$ smooth, without microspines (Fig. 10); pore $\mathrm{PA}_{\mathrm{a}}$ located proximad of level of seta $\mathrm{PA}_{1}$ (Fig. 10) .................. Paratachys Casey, 1918

6 Pore $\mathrm{PR}_{\mathrm{h}}$ on protergum absent (as on Fig. 58) . Tachys Dejean, 18 Pore $\mathrm{PR}_{\mathrm{h}}$ on protergum present (as on Figs 59,60 ) $\ldots . .7$

7 Pore $\mathrm{PA}_{b}$ on parietale absent (as on Fig. 52) .......... .............. Polyderis Motschulsky, 1862 (in part)

- Pore $\mathrm{PA}_{\mathrm{b}}$ on parietale present (Figs 6-8) ........ 8

8 Parietale laterad of seta $\mathrm{PA}_{3}$ with microspines (Fig. 7); seta $\mathrm{FR}_{9}$ on frontale more than twice longer than $\mathrm{FR}_{5}$ (Fig. 7) ..

Elaphropus Motschulsky, 1839

- Parietale laterad of seta $\mathrm{PA}_{3}$ smooth, without microspines (Fig. 6); seta $\mathrm{FR}_{9}$ on frontale about as long as $\mathrm{FR}_{5}$ (Fig. 6) . ............ Polyderis Motschulsky, 1862 (in part)

\section{Key to genera of second and third instars of Tachyina and Xystosomina larvae}

1 Ocular groove present (Fig. 49); cephalic capsule laterally rounded (Fig. 49); group gMX on stipes with 5 setae (Fig. 46); lateral sides of ninth tergum without long secondary seta at middle (Fig. 57) . . . . . . . . Tachyta Kirby, 1837

- Ocular groove absent (Figs 50-56); cephalic capsule parallel-sided (Figs 50-56); group gMX on stipes with 6 setae (Figs 47-48); lateral sides of ninth tergum with long secondary seta at middle (Figs 58-60) . . . . . . . 2 2

2 Mandible with teeth on terebra (Figs 54-56) ........ 3

- Mandible without teeth on terebra (Figs 50-53) ..... 5

3 Terebra with more than 10 small and equal teeth (Fig. 54) . . . . . . . . . . . . . . . . . Sphaerotachys G. Müller, 1926

- Terebra with 4-7 large teeth on proximal half (Figs 55-56) .................................. 4

4 Frontale more elongated (ratio length/width 1.5) (Fig. 55); pore $\mathrm{PA}_{\mathrm{a}}$ located posteriad to level of seta $\mathrm{PA}_{1}$ (Fig. 55) ... . Paratachys Casey, 1918

- Frontale less elongated (ratio length/width 1.3) (Fig. 56); pore $\mathrm{PA}_{\mathrm{a}}$ located at level of seta $\mathrm{PA}_{1}$ (Fig. 56) .......... Porotachys Netolitzky, 1914

5 Pore $\mathrm{PR}_{\mathrm{h}}$ on protergum absent (Fig. 58)

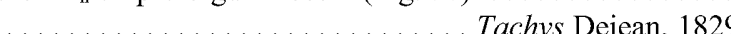

Pore $\mathrm{PR}_{\mathrm{h}}$ on protergum present (Fig. 59) ............ ............... Elaphropus Motschulsky, 1839 


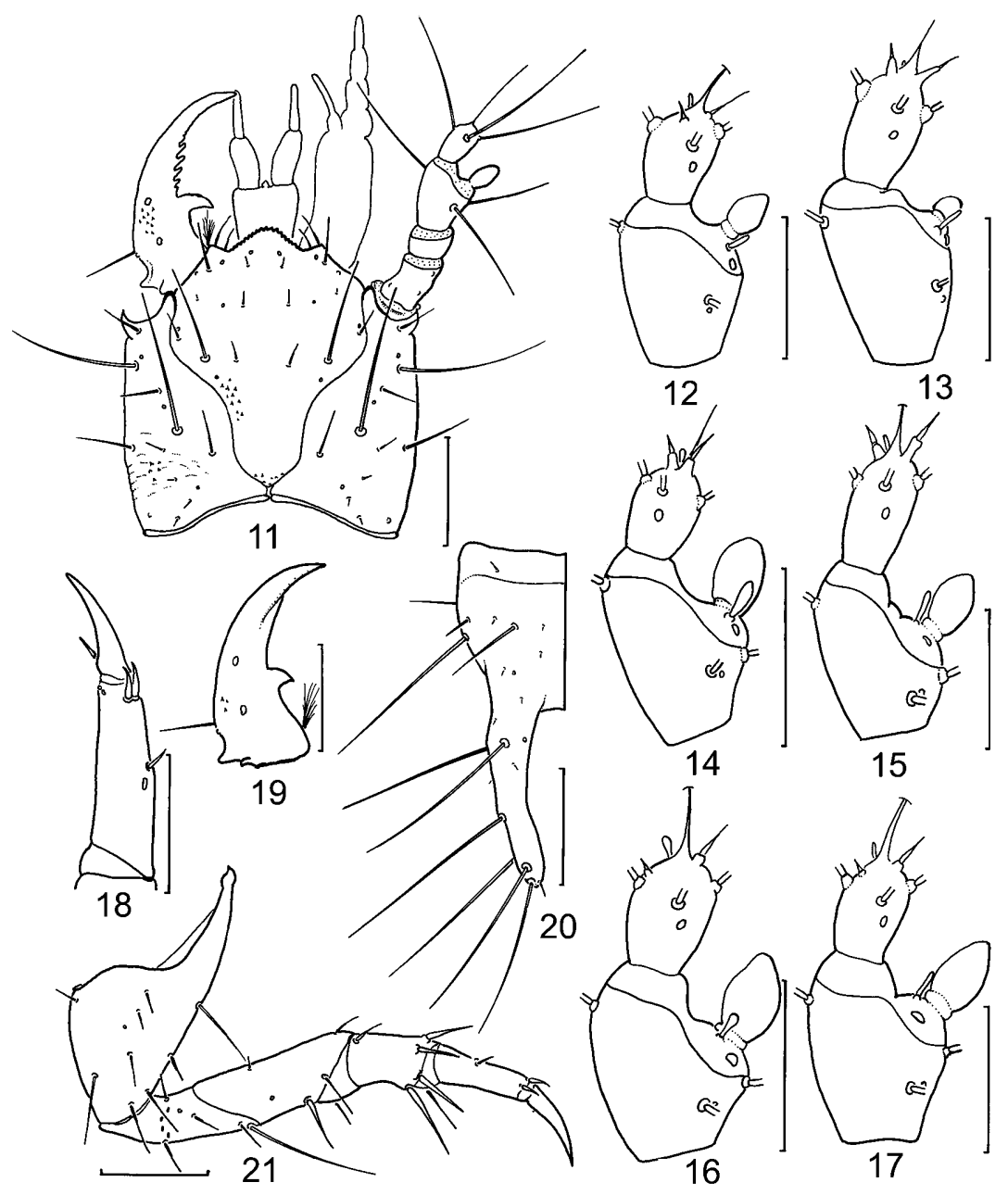

Figs 11-21: Larvae of Tachyina and Xystosomina, details. 11-19 - first instar; 20 - second instar; 21 - third instar. 11-17, 19, 20 - dorsal view; 18, 21 - anterior view. 11 - cephalic capsule, right antenna, left mandible; 12-17 - antennomeres III and IV (long setae omitted); 18 - claw and tarsus; 19 - left mandible; 20 - left half of urogomphi; 21 - leg. 11, 17 - Porotachys bisulcatus; 12 Mioptachys flavicauda; 13, 18 - Tachyta nana; 14 - Tachys scutellaris; 15 - Elaphropus diabrachys; 16 - Paratachys bistriatus; 19 - Tachys halophilus; 20 - Polyderis laevis; 21 - Tachys centriustatus. Scale bars: 11, 19-21: 0.1 mm; 12-18: 0.05 mm.

\section{SUBTRIBE XYSTOSOMINA}

\section{Genus Mioptachys Bates, 1882}

Diagnosis. First-instar larvae of this genus can be recognised by the presence of egg-bursters on the frontale in combination with absence of microsculpture on the dorsal surface of the parietale.

Description. First instar. Cephalic capsule flat, laterally rounded (Fig. 3); frontal sutures U-shaped posteriad; frontale with egg-bursters consisting of two longitudinal rows of spinules, without microspines at base; parietale smooth, without microspines laterad of seta $\mathrm{PA}_{3}$; pore $\mathrm{PA}_{\mathrm{b}}$ present at level of seta $\mathrm{PA}_{2}$; seta $\mathrm{FR}_{4}$ as short as diameter of seta $\mathrm{FR}_{2}$; seta $\mathrm{FR}_{6}$ removed proximad and closer to $\mathrm{FR}_{\mathrm{f}}$ than to $\mathrm{FR}_{\mathrm{e}}$; seta $\mathrm{FR}_{9}$ normal, about $3-5 \times$ longer than $\mathrm{FR}_{5}$; sensorium on antennomere III larger than in Tachyta (Figs 3, 12), but smaller than in remaining taxa; dorsal surface of mandible near pore $\mathrm{MN}_{\mathrm{b}}$ without microspines (Fig. 3); terebra without serration; group gMX on stipes with 6 setae (Fig. 40); second galeomere about 5 times longer than first; pore $\mathrm{MX}_{\mathrm{c}}$ in distal fourth of ventral surface of stipes; distal seta of group $\mathrm{gMX}$ on stipes anteriad of level of seta $\mathrm{MX}_{5}$; pore $\mathrm{PR}_{\mathrm{h}}$ on protergum present; setae $\mathrm{PR}_{13}, \mathrm{ME}_{14}$, and $\mathrm{TE}_{11}$ about 3-5× longer than proximal diameter of setae $\mathrm{PR}_{12}$, $\mathrm{ME}_{13}$, and $\mathrm{TE}_{10}$ respectively; seta on claw as long as a half of proximal diameter of claw. Second and third instars. Unknown to us, briefly described by Thompson (1979). According to his drawings, cephalic capsule laterally rounded.

Monophyly and phylogenetic relationships. Studied larvae of the genus Mioptachys possess only one unique, probably apomorphic morphological character state: the presence of six setae in group gMX on the stipes in firstinstar larvae instead of five setae. Beside that, Mioptachys larvae exhibit some similarities with those of the genus Tachyta, which we regard as convergences; these character states are discussed under Tachyta. Because second and third instars of Mioptachys are unknown, the relationships of the genus are unclear.

Remarks. Recently Erwin (1994: 560) has erected a new subtribe Xystosomina and provided a number of adult character states to distinguish it from other subtribes 


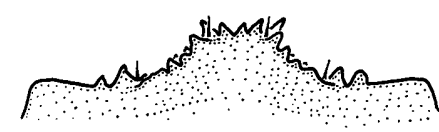

22

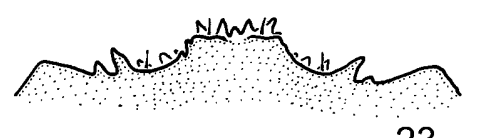

23

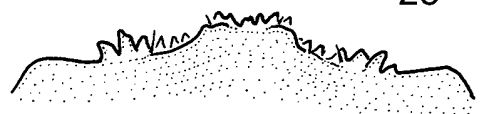

24

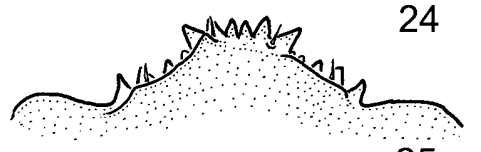

25

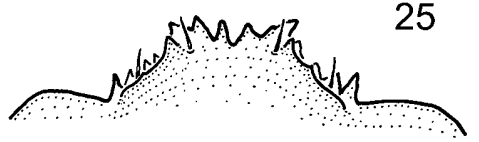

26

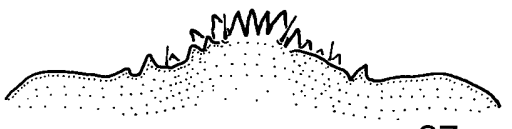

27

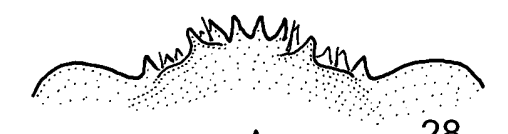

28

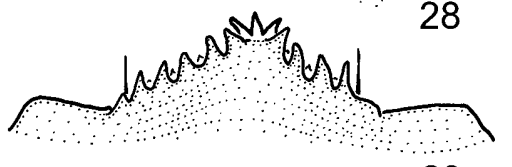

29

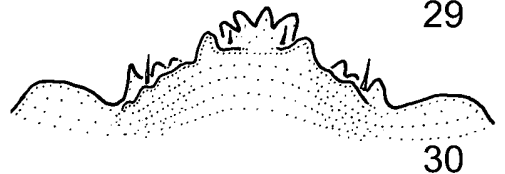

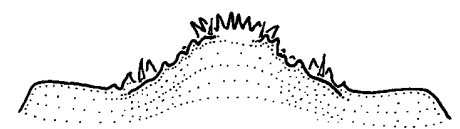

31

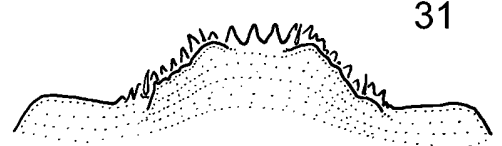

32
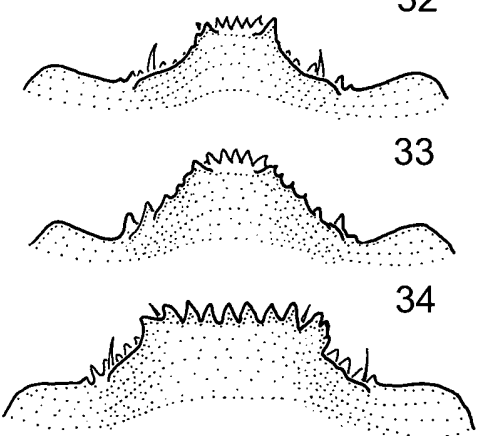

35

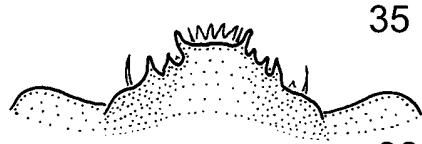

36

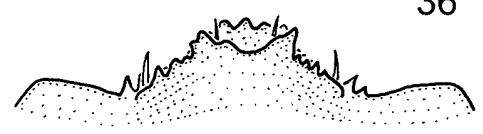

37

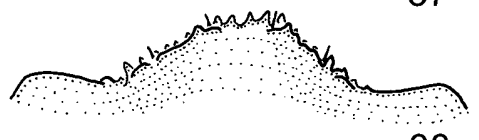

38

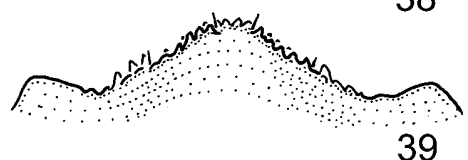

Figs 22-39: Larvae of Tachyina and Xystosomina, nasale, dorsal view. 22, 23, 25, 27, 29, 31, 33, 34, 36, 38 - first instar; 26,30 second instar; 24, 28, 32, 35, 37, 39 - third instar. 22 - Mioptachys flavicauda; 23, 24 - Tachyta nana; 25, 26 - Tachys scutellaris; 27, 28 - Tachys centriustatus; 29 - Polyderis ?rufotestacea; 30 - Polyderis laevis; 31, 32 - Elaphropus diabrachys; 33 - Elaphropus tripunctatus; 34, 35 - Sphaerotachys haemorrhoidalis; 36, 37 - Paratachys bistriatus; 38, 39 - Porotachys bisulcatus.

of Bembidiini. The subtribe Xystosomina includes the genera Mioptachys Bates, 1882, Inpa Erwin, 1978, Philipis Erwin, 1994, Geballusa Erwin, 1994, Gouleta Erwin, 1994, Batesiana Erwin, 1994, and Xystosomus Schaum, 1859. Immature stages are unknown for all of these genera except Mioptachys.

Geographical distribution and diversity. The genus Mioptachys includes about 12 described species which are distributed from southern Canada to northern Argentina including Hispaniola (Erwin, 1994).

\section{Mioptachys flavicauda (Say, 1823)}

(Figs 3, 12, 22, 40)

Diagnosis. See Diagnosis section of the genus.

Description. First-instar larvae. HW $=0.18 \mathrm{~mm}$, HL $=0.17 \mathrm{~mm}(\mathrm{n}=1)$. Nasale: Fig. 22. Second and third instars. Not available.

Material studied. $2 \mathrm{~L}_{1}$ (mounted on slide) reared from adults collected on June 7, 1987, Rocky Narrows, Massachusetts, USA, D. Maddison (DRM 87003).

\section{SUBTRIBE TACHYINA}

\section{Genus Tachyta Kirby, 1837}

Diagnosis. First-instar larvae of this genus are unique in the presence of egg-bursters in combination with the presence of meshed microsculpture dorsolaterad on the parietale. Second and third instars of Tachyta may be immediately recognised by at least two unique features: the galea is shorter than two proximal maxillary palpomeres combined, and the secondary seta at middle of lateral side of ninth abdominal tergum is absent.

Description. All instars. Cephalic capsule flat, laterally rounded (Fig. 4); pore $\mathrm{PA}_{\mathrm{b}}$ located distal of level of seta $\mathrm{PA}_{2}$; sensorium on antennomere III small (Fig. 13); terebra without serration; pore $\mathrm{MX}_{\mathrm{c}}$ in distal fourth of ventral surface of stipes; distal seta of group gMX on stipes posteriad of level of seta $\mathrm{MX}_{5}$; pore $\mathrm{PR}_{\mathrm{h}}$ on protergum present; setae $\mathrm{PR}_{13}, \mathrm{ME}_{14}$, and $\mathrm{TE}_{11}$ about $3-5 \times$ shorter than proximal diameter of setae $\mathrm{PR}_{12}, \mathrm{ME}_{13}$, and $\mathrm{TE}_{10}$ respectively; seta on claw as long as proximal diameter of claw. First instar. Frontal sutures U-shaped 

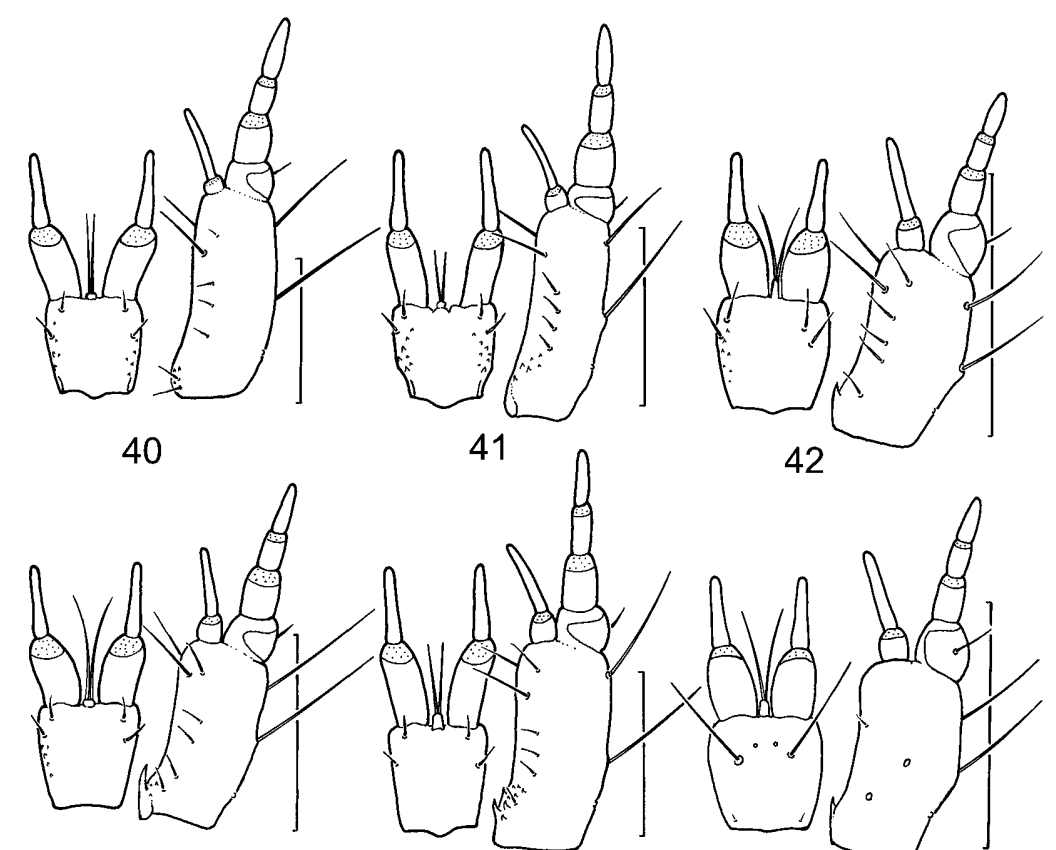

43
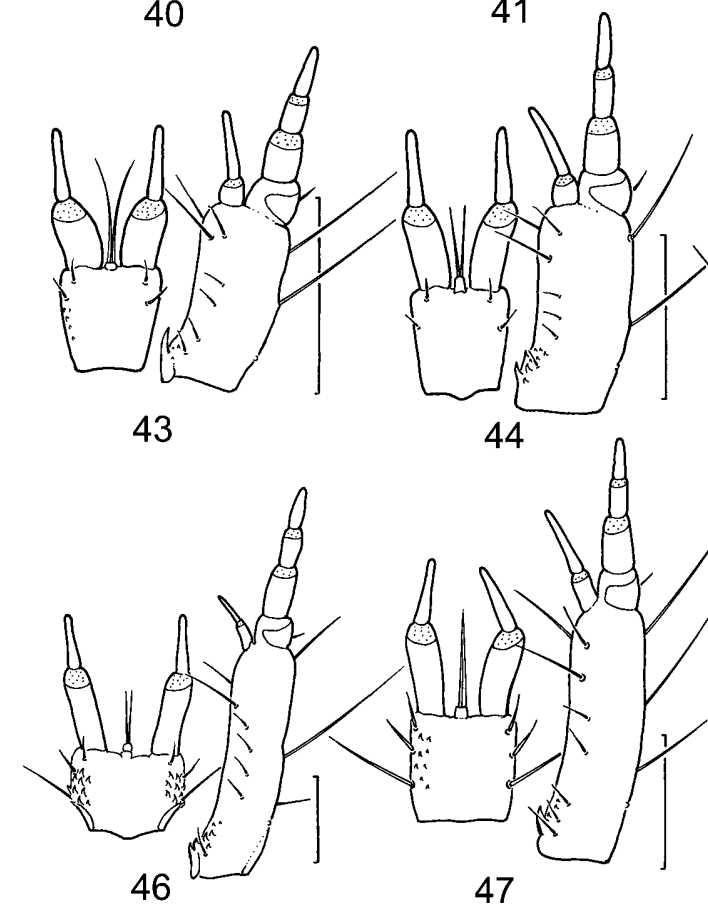

44

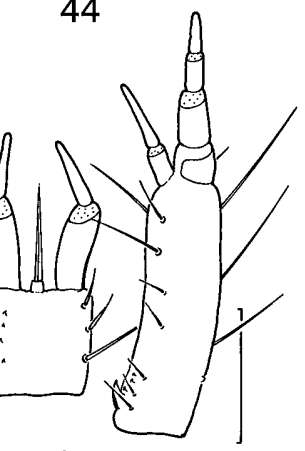

47
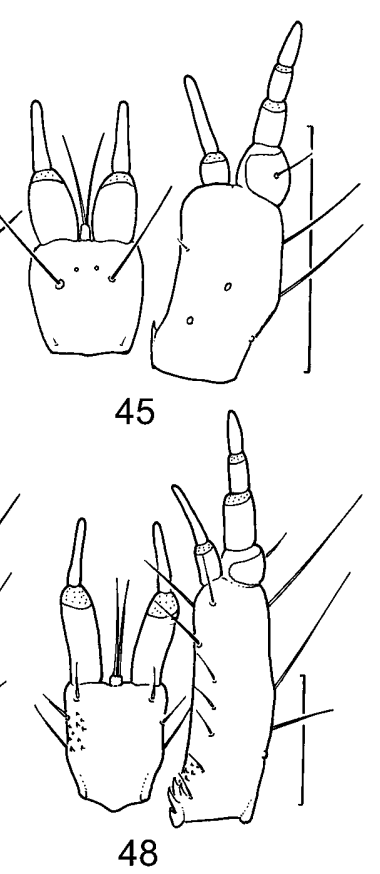

Figs 40-48: Larvae of Tachyina and Xystosomina, details. 40-45 - first instar; 46-48 - third instar. 40-44, 46-48 - labium and right maxilla, dorsal view; 45 - labium and left maxilla, ventral view. 40 - Mioptachys flavicauda; 41, 46 - Tachyta nana; 42, 45 Tachys scutellaris; 43 - Sphaerotachys haemorrhoidalis; 44, 48 - Porotachys bisulcatus; 47 - Elaphropus diabrachys. Scale bars: $0.1 \mathrm{~mm}$.

posteriad (Fig. 4); frontale with egg-bursters consisting of two longitudinal rows of spinules and without microspines at base; parietale with meshed microsculpture laterad of seta $\mathrm{PA}_{3}$; seta $\mathrm{FR}_{4}$ about $3-5 \times$ longer than diameter of seta $\mathrm{FR}_{2}$; seta $\mathrm{FR}_{6}$ at normal position, closer to $\mathrm{FR}_{\mathrm{e}}$ than to $\mathrm{FR}_{\mathrm{f}}$; seta $\mathrm{FR}_{9}$ normal, about $3-5 \times$ longer than $\mathrm{FR}_{5}$; dorsal surface of mandible near pore $\mathrm{MN}_{\mathrm{b}}$ without microspines; group gMX on stipes with 4 setae (Fig. 4); second galeomere about $4 \times$ longer than first (Fig. 41). Second and third instars. Ocular groove present (Fig. 49); group gMX on stipes with 5 setae (Fig. 46); galea shorter than two proximal maxillary palpomeres combined; terga with few secondary setae (Fig. 57); lateral side of ninth abdominal tergum without secondary seta at middle (Fig. 57).

Monophyly and phylogenetic relationships. The single Tachyta species studied has six presumable larval autapomorphies: (1) the claw seta long and thin, as long as proximal width of claw; (2) antennomere III with small sensorium; (3) first-instar larvae with only four setae in group gMX on stipes instead of five; (4) second and third instars with very short galea, which is shorter than two proximal maxillary palpomeres combined; (5) secondand third-instar larvae with only a few secondary setae on terga; (6) lateral side of ninth abdominal tergum in second and third instars without secondary seta at middle.

Second and third instars of the genus Tachyta also have a notable plesiomorphy: the presence of an ocular groove on the cephalic capsule, a feature unique within Tachyina + Xystosomina.

It should be mentioned that Tachyta larvae share some character states with those of Mioptachys. However, we do not use them to link the genera as closely related taxa. We consider two of these characters to be convergent similarities due to similar way of life under bark of logs. This derived strategy is unique within the discussed genera of Tachyina and Xystosomina. These characters are: (1) cephalic capsule depressed and laterally rounded (Figs 3, 4) and (2) frontal sutures U-shaped posteriad (Figs 3,4). Adaptive value of the depressed cranium is obvious for larvae living under bark. We propose that the wider and laterally rounded cranium, as well as the shape 


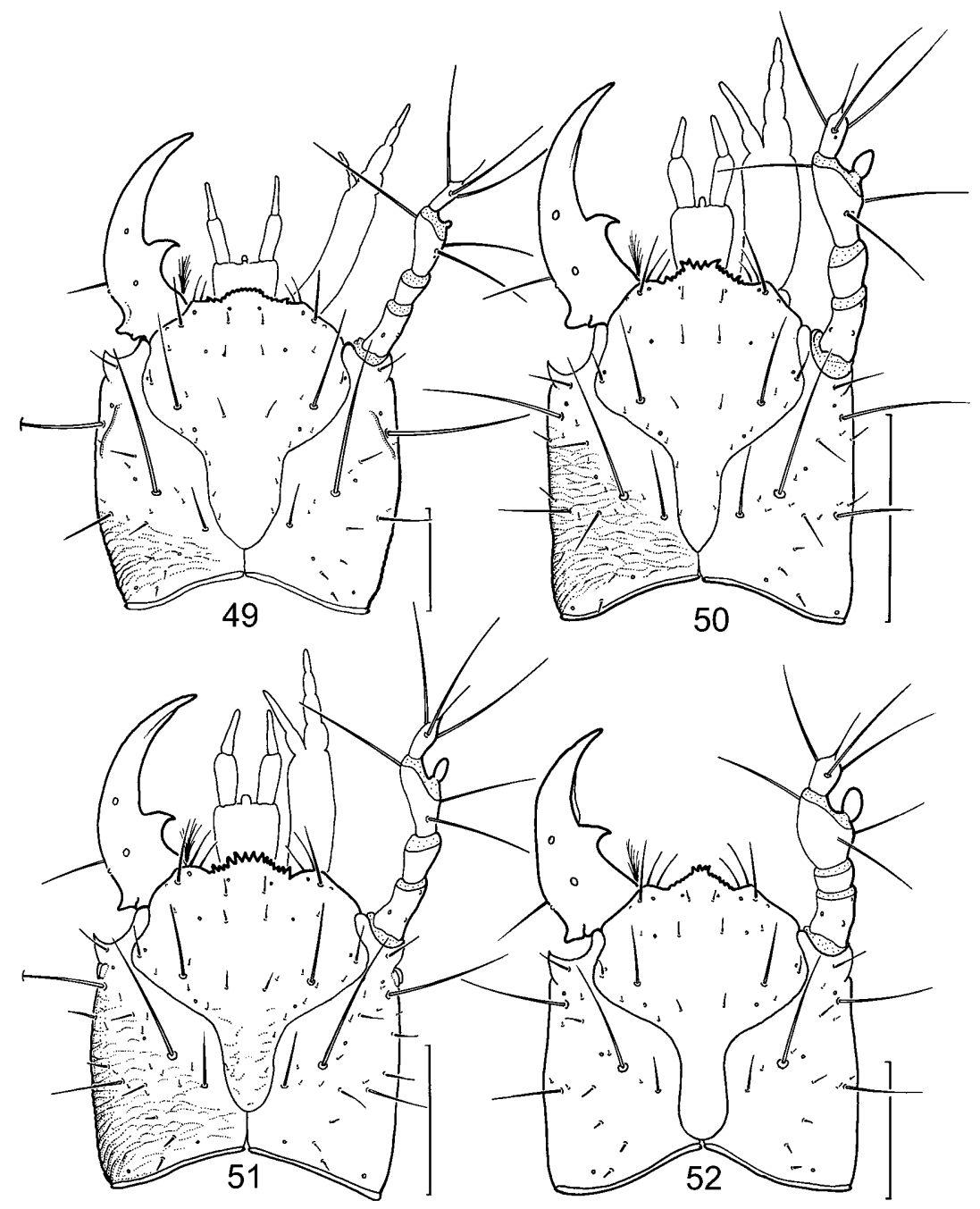

Figs 49-52: Larvae of Tachyina, cephalic capsule, right antenna and left mandible, dorsal view. 49, 51 - third instar; 50, 52 second instar. 49 - Tachyta nana; 50 - Tachys scutellaris; 51 - Tachys centriustatus; 52 - Polyderis laevis. Scale bars: $0.2 \mathrm{~mm}$.

of the base of frontale, are connected to the depressed cranium. Consequently, we believe that the discussed characters have been acquired independently as a result of subcortical larval habits.

The remaining two characters, namely (3) frontale in first-instar larvae with egg-bursters and (4) dorsal surface of mandible near pore $\mathrm{MN}_{\mathrm{b}}$ in first-instar larvae without microspines, are considered as being of uncertain phylogenetic value. Absence of egg-bursters in first instar is generally considered as a derived character state in carabid larvae, but egg-bursters are lacking in at least one Patrobitae species (Bousquet \& Grebennikov, 1999). However, the presence of markedly developed eggbursters on frontale in first-instar larvae, similar to those of Mioptachys and Tachyta, was also recorded for members of some other Trechitae taxa: the genus Asaphidion (by several authors, SEM picture and earlier references in Maddison, 1993) and the subgenus Metallina Motschulsky, 1850 of the genus Bembidion (our data, unpubl.). In addition to this, markedly developed egg-bursters were found not only on frontale but also on parietale of firstinstar larvae of two rather unrelated groups within Trechi- tae: some Bembidion species (Maddison, 1993) and the monobasic pogonine genus Thalassotrechus (Grebennikov \& Bousquet, unpubl.). An even more complicated pattern was found for the presence or absence of microspines on mandible in first-instar Trechitae (our data, unpubl.); this character is poorly known outside the supertribe. We therefore prefer not to use the above characters for phylogenetic purposes.

Geographical distribution and diversity. The genus Tachyta, according to Erwin's review (1975), is distributed in all zoogeographical regions of the World and includes 19 species arranged in two subgenera. Recently Baehr (1986) described a new species of Tachyta from Australia, and Erwin and Kavanaugh (unpubl.) discovered another from China.

\section{Tachyta nana (Gyllenhal, 1810)}

(Figs 1, 4, 13, 18, 23, 24, 41, 46, 49, 57, 61)

Diagnosis. See Diagnosis section of the genus.

Description. First-instar larvae. $H W=0.28-0.29$ $\mathrm{mm}, \mathrm{HL}=0.27-0.28 \mathrm{~mm}(\mathrm{n}=4)$. Nasale: Fig. 23. Second and third instars. $\mathrm{HW}=0.39-0.42 \mathrm{~mm}, \mathrm{HL}=$ 

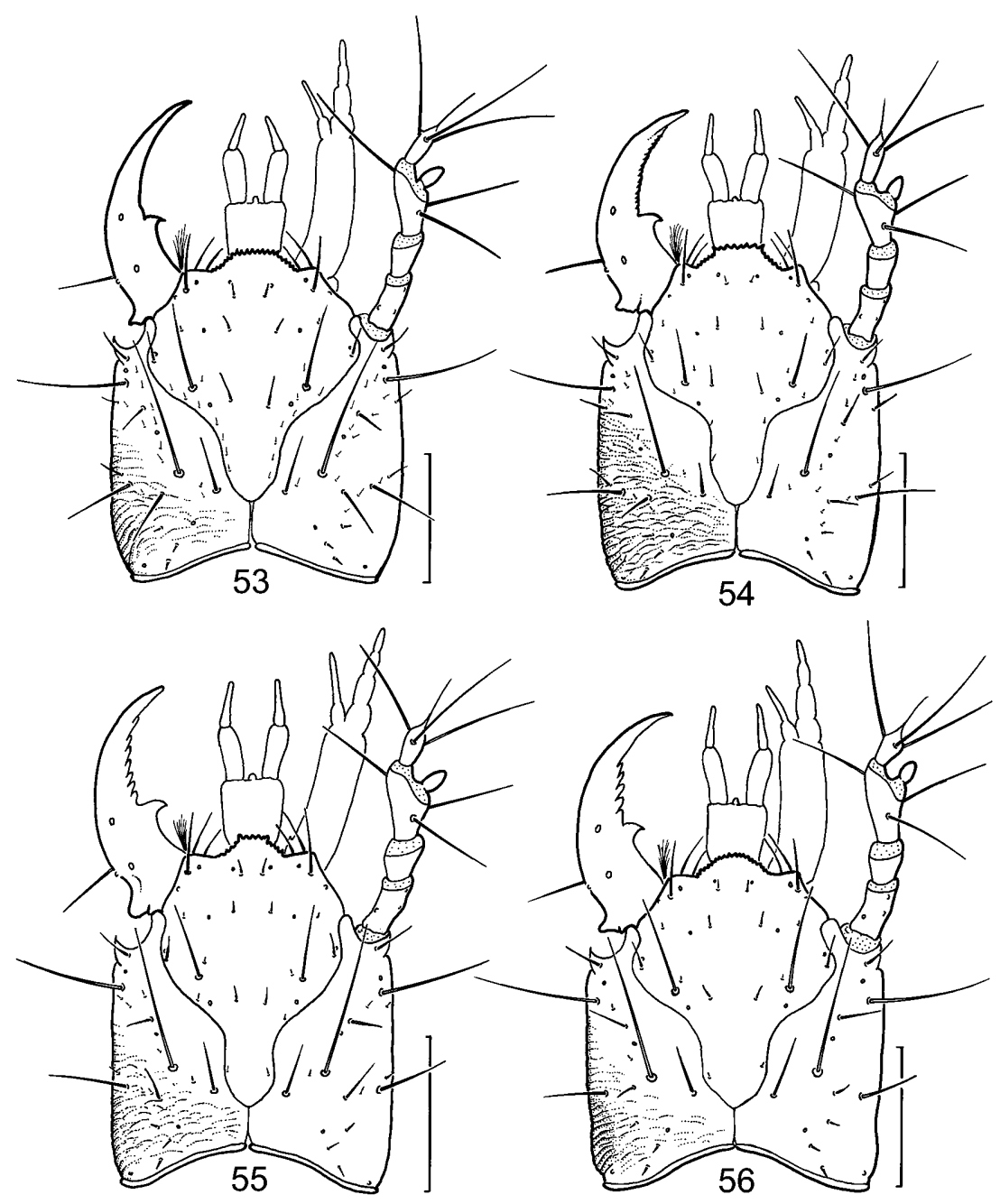

Figs 53-56: Larvae of Tachyina, third instar, cephalic capsule, right antenna and left mandible, dorsal view. 53 - Elaphropus diabrachys; 54 - Sphaerotachys haemorrhoidalis; 55 - Paratachys bistriatus; 56 - Porotachys bisulcatus. Scale bars: $0.2 \mathrm{~mm}$.

$0.36-0.37 \mathrm{~mm}(\mathrm{n}=2)$ in second instar and $\mathrm{HW}=$ $0.52-0.58 \mathrm{~mm}, \mathrm{HL}=0.52-0.55 \mathrm{~mm}(\mathrm{n}=2)$ in third instar. Nasale: Fig. 24.

Material studied. $4 \mathrm{~L}_{1}, 2 \mathrm{~L}_{2}, 2 \mathrm{~L}_{3}$ (mounted on slide) reared from adults collected on April 10, 1995, Mezmay, Krasnodar distr., northwestern part of Caucasus Range, Russia, V. Grebennikov (VVG). Additional material reared but not studied in detail includes $14 \mathrm{~L}_{1}, 1 \mathrm{~L}_{2}, 11 \mathrm{~L}_{3}$ from the same place.

Remarks. Our material represents the nominotypical Palaearctic subspecies, Tachyta nana nana. We could not find any significant larval morphological differences between the nominotypical subspecies and the Nearctic subspecies Tachyta nana inornata described by Erwin (1975).

\section{Genus Tachys Dejean, 1829}

Diagnosis. All instars of Tachys have one unique feature, namely the lack of pore $\mathrm{PR}_{\mathrm{h}}$ on protergum (Fig. 58). First-instar larvae can be recognised from other Trechitae taxa (except Polyderis) by the combination of smooth terebra and absence of egg-bursters on frontale. Second and third instars of Tachys bear the highest number of secondary setae on terga and have a characteristic shape of urogomphi (Fig. 58).
Description. All instars. Cephalic capsule subcylindrical, parallel-sided (Fig. 5); pore $\mathrm{PA}_{\mathrm{b}}$ present proximad of level of seta $\mathrm{PA}_{2}$; sensorium on antennomere III large (Fig. 14); terebra without serration; pore $\mathrm{MX}_{\mathrm{c}}$ at middle of ventral surface of stipes (Fig. 45); distal seta of group gMX on stipes anteriad of level of seta $\mathrm{MX}_{5}$; pore $\mathrm{PR}_{\mathrm{h}}$ on protergum absent (Fig. 58); setae $\mathrm{PR}_{13}, \mathrm{ME}_{14}$, and $\mathrm{TE}_{11}$ about 3-5× longer than proximal diameter of setae $\mathrm{PR}_{12}$, $\mathrm{ME}_{13}$, and $\mathrm{TE}_{10}$ respectively; seta on claw as short as $1 / 4$ proximal diameter of claw. First instar. Frontal sutures $\mathrm{V}$-shaped posteriad (Fig. 5); frontale without egg-bursters but with microspines at base and near pore $\mathrm{FR}_{\mathrm{b}}$; parietale with microspines laterad of seta $\mathrm{PA}_{3}$; seta $\mathrm{FR}_{4}$ about $3-5 \times$ longer than diameter of seta $\mathrm{FR}_{2}$; seta $\mathrm{FR}_{6}$ closer to $\mathrm{FR}_{\mathrm{e}}$ than to $\mathrm{FR}_{\mathrm{f}}$; seta $\mathrm{FR}_{9}$ normal, about 3-5× longer than $\mathrm{FR}_{5}$; dorsal surface of mandible near pore $\mathrm{MN}_{\mathrm{b}}$ with microspines; group gMX on stipes with 5 setae (Fig. 42); second galeomere about $3 \times$ longer than first (Figs 42, 45). Second and third instars. Ocular groove absent (Figs $50,51)$; group gMX on stipes with 6 setae; galea longer than two proximal maxillary palpomeres combined; terga with numerous secondary setae (Fig. 58); lateral side of ninth abdominal tergum with secondary seta at middle. 


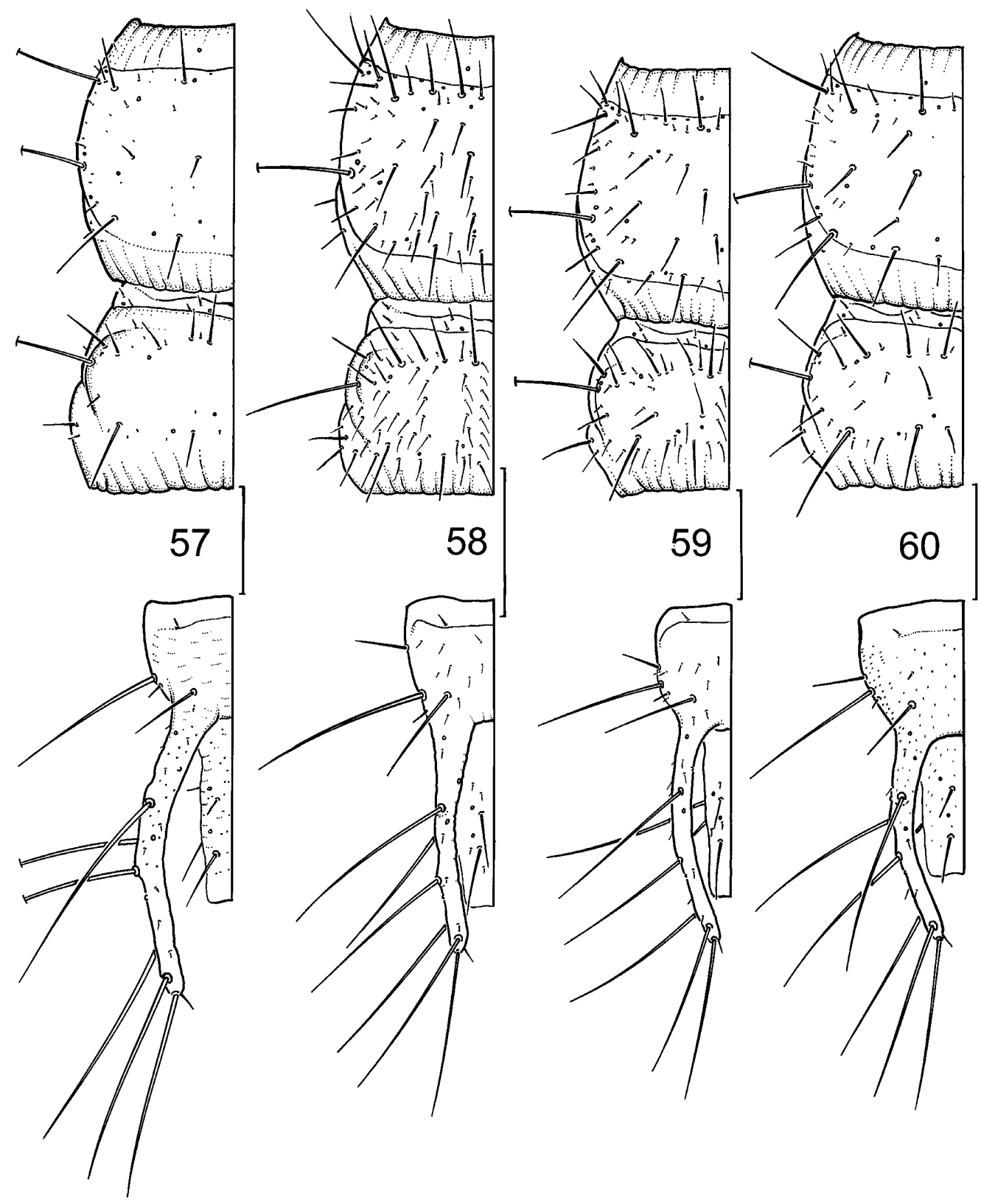

Figs 57-60: Larvae of Tachyina, left half of prothorax, mesothorax, urogomphi and pygidium, dorsal view. 57, 59, 60 - thirdinstar larvae; 58 - second-instar larva. 57 - Tachyta nana; 58 - Tachys scutellaris; 59 - Elaphropus diabrachys; 60 - Porotachys bisulcatus. Scale bars: $0.2 \mathrm{~mm}$.

Monophyly and phylogenetic relationships. Studied larvae of the genus Tachys exhibit three autapomorphic character states which support monophyly of the genus: (1) pore $\mathrm{PA}_{\mathrm{b}}$ on parietale is removed proximad and located posteriorly of level of seta $\mathrm{PA}_{2} ;(2)$ pore $\mathrm{PR}_{\mathrm{h}}$ on protergum is absent (the last feature has been noted also for larvae of the pogonine genus Cardiaderus and the bembidiine genera Bembidion and Asaphidion, unpubl.). (3) Relatively high number of secondary setae on thoracic and abdominal sclerites in second and third instars.

Larvae of the genus Tachys share with those of Polyderis one apomorphic character state: pore $\mathrm{MX}_{\mathrm{c}}$ on ventral surface of stipes removed proximad and located at middle of stipes (Fig. 45) instead of distal quarter.
Geographical distribution and diversity. The genus Tachys (which is considered as a subgenus Tachys s. str. of a more-inclusive genus Tachys by Kryzhanovskij, 1983 and Kryzhanovskij et al., 1995) has not been recently revised, so we repeat Kryzhanovskij's (1983) remark that it has up to 50 species, mainly in the Holarctic Region, but with some in Africa and one in Argentine.

Tachys scutellaris (Stephens, 1829)

(Figs 5, 14, 25, 26, 42, 45, 50, 58)

Diagnosis. Larvae of this species differ from those of $T$. centriustatus by the shape of nasale and by a smaller cephalic capsule; from those of $T$. halophilus - by the 


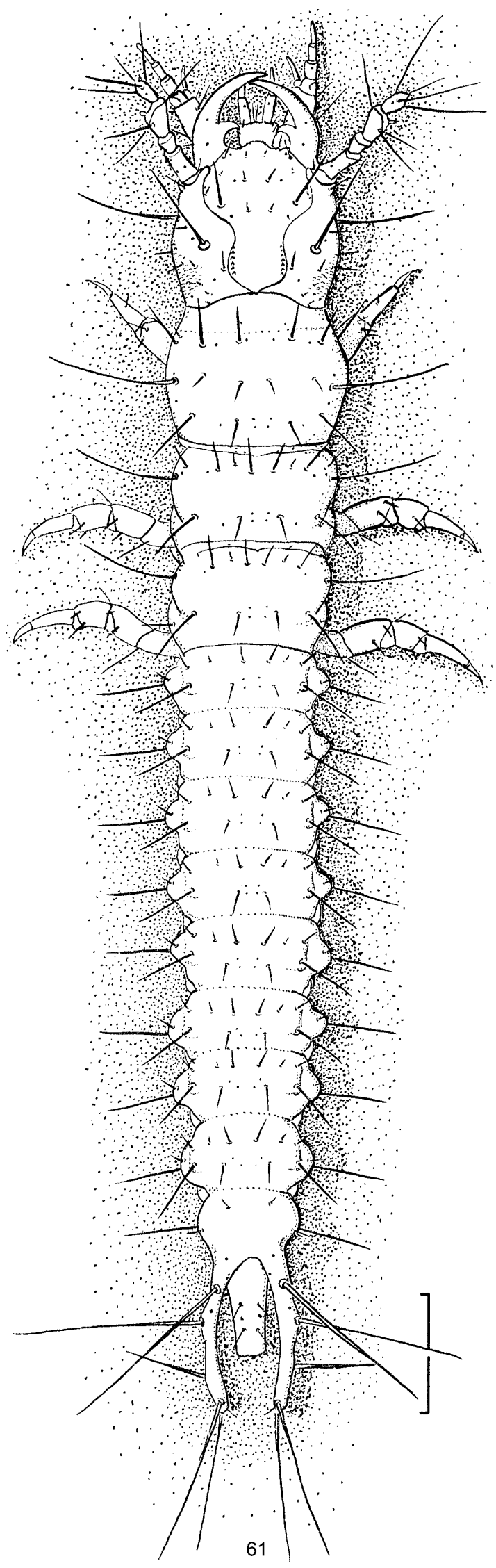

Fig. 61. First-instar larva of Tachyta nana, habitus, dorsal view. Scale bar: $0.2 \mathrm{~mm}$. shape of the mandible. We could not find differences between larvae of $T$. scutellaris and $T$. vittatus.

Description. First-instar larvae. $\mathrm{HW}=0.19-0.21$ $\mathrm{mm}, \mathrm{HL}=0.17-0.18 \mathrm{~mm}(\mathrm{n}=6)$. Nasale: Fig. 25 . Second and third instars. $\mathrm{HW}=0.28 \mathrm{~mm}, \mathrm{HL}=0.29$ $\mathrm{mm}(\mathrm{n}=1)$ in second instar. Nasale: Fig. 26. Larvae of third instar not available.

Material studied. $5 \mathrm{~L}_{1}, 4 \mathrm{~L}_{2}$ (mounted on slide) reared from adults collected on May 22, 1995, Sarepta, Volgograd, Russia, V. Grebennikov (VVG). Additional material reared but not studied in detail includes $11 \mathrm{~L}_{1}, 1 \mathrm{~L}_{2}$ from the same place. $4 \mathrm{~L}_{1}$, $1 \mathrm{~L}_{2}$ (mounted on slide) reared from adults collected on April 25, 1995, Kuyalnisky Liman, Odessa distr., Ukraine, V. Grebennikov (VVG). Additional material reared but not studied includes $10 \mathrm{~L}_{1}$ from the same place. $4 \mathrm{~L}_{1}, 1 \mathrm{~L}_{2}$ (mounted on slide) reared from adults collected on May 25, 1995, Baskunchak Lake, Astrakhan' distr., Russia, V. Grebennikov (VVG).

\section{Tachys vittatus Motschulsky, 1850}

Diagnosis. We did not find structural differences between larvae of this species and T. scutellaris.

Description. First-instar larvae. $H W=0.19-0.20$ $\mathrm{mm}, \mathrm{HL}=0.17-0.18 \mathrm{~mm}(\mathrm{n}=2)$. Nasale: Fig. 25 . Second and third instars. $\mathrm{HW}=0.28 \mathrm{~mm}, \mathrm{HL}=0.29$ $\mathrm{mm}(\mathrm{n}=1)$ in second-instar. Nasale: Fig. 26. Third-instar larvae not available.

Material studied. $6 \mathrm{~L}_{1}, 4 \mathrm{~L}_{2}$ (mounted on slide) reared from adults collected on May 25, 1995, Baskunchak Lake, Astrakhan' distr., Russia, V. Grebennikov (VVG). Additional material reared but not studied in detail includes $12 \mathrm{~L}_{1}, 2 \mathrm{~L}_{2}$ from the same place.

\section{Tachys halophilus Lindroth, 1966 (Fig. 19)}

Diagnosis. First-instar larvae of this species differ from those of remaining Tachys by shape of the mandible which is wider in proximal half than that of other species (Fig. 19).

Description. First-instar larvac. $\mathrm{HW}=0.22 \mathrm{~mm}, \mathrm{HL}$ $=0.18 \mathrm{~mm}(\mathrm{n}=1)$. Nasale: Fig. 25. Mandible wider in proximal half than that of other species. Second and third instars. Not available.

Material studied. $2 \mathrm{~L}_{1}$ (mounted on slide) reared from adults collected on May 16, 1986, Chaplin Lake, Saskatchewan, Canada, D. Maddison (DRM 86013).

\section{Tachys centriustatus Reitter, 1874}

(Figs 2, 21, 27, 28, 51)

Diagnosis. Larvae of this species differ from those of other Tachys by having the nasale less projected at middle (Fig. 28).

Description. First-instar larvae. $\mathrm{HW}=0.21-0.22$ $\mathrm{mm}, \mathrm{HL}=0.19-0.20 \mathrm{~mm}(\mathrm{n}=2)$. Nasale: Fig. 27. Second and third instars. $\mathrm{HW}=0.27 \mathrm{~mm}, \mathrm{HL}=0.28$ $\mathrm{mm}(\mathrm{n}=1)$ in second instar and $\mathrm{HW}=0.42 \mathrm{~mm}, \mathrm{HL}=$ $0.42 \mathrm{~mm}(\mathrm{n}=1)$ in third instar. Nasale: Fig. 28.

Material studied. $2 \mathrm{~L}_{1}, 1 \mathrm{~L}_{2}, 1 \mathrm{~L}_{3}$ (mounted on slide) reared from adults collected on May 25, 1995, Baskunchak Lake, Astrakhan' distr., Russia, V. Grebennikov (VVG). Additional material reared but not studied in detail includes $8 \mathrm{~L}_{1}, 3 \mathrm{~L}_{2}$ from the same place. 
Remarks. In the Russian carabid checklist (Kryzhanovskij et al., 1995) T. centriustatus is treated as a member of the subgenus Paratachys of the genus Tachys. Erwin (1974a) considers Paratachys as a separate genus which is supported by the present study of the larval morphology. Larvae of $T$. centriustatus share all apomorphic features of the genus Tachys and, consequently, we treat it as a member of this genus, not of Paratachys. This taxonomic action should be confirmed by study of adult morphology.

\section{Genus Polyderis Motschulsky, 1862}

Diagnosis. Known larvae of this genus differ by the character states listed in the key to genera of larvae.

Description. All instars. Cephalic capsule subcylindrical, parallel-sided (Fig. 6); pore $\mathrm{PA}_{\mathrm{b}}$ absent or present distad of level of seta $\mathrm{PA}_{2}$; sensorium on antennomere III large; terebra without serration; pore $\mathrm{MX}_{\mathrm{c}}$ at middle of ventral surface of stipes (as on Fig. 45); distal seta of group gMX on stipes anteriad of level of seta $\mathrm{MX}_{5}$; pore $\mathrm{PR}_{\mathrm{h}}$ on protergum present; setae $\mathrm{PR}_{13}, \mathrm{ME}_{14}$, and $\mathrm{TE}_{11}$ about 3-5 $\times$ longer than proximal diameter of setae $\mathrm{PR}_{12}$, $\mathrm{ME}_{13}$, and $\mathrm{TE}_{10}$ respectively; seta on claw as short as $1 / 4$ of proximal diameter of claw. First instar. Frontal sutures V-shaped posteriad (Fig. 6); frontale without eggbursters but with microspines at base; parietale smooth, without microsculpture laterad of seta $\mathrm{PA}_{3}$; seta $\mathrm{FR}_{4}$ about 3-5 $\times$ longer than diameter of seta $\mathrm{FR}_{2}$; seta $\mathrm{FR}_{6}$ closer to $\mathrm{FR}_{\mathrm{e}}$ than to $\mathrm{FR}_{\mathrm{f}}$; seta $\mathrm{FR}_{9}$ normal, about $3-5 \times$ longer than $\mathrm{FR}_{5}$, or short, not longer than $\mathrm{FR}_{5}$; dorsal surface of mandible near pore $\mathrm{MN}_{\mathrm{b}}$ with microspines; group $\mathrm{gMX}$ on stipes with 5 setae; second galeomere about $3 \times$ longer than first. Second and third instars. Ocular groove absent (Fig. 52); group gMX on stipes with 6 setae; galea longer than two proximal maxillary palpomeres combined; terga with number of secondary setae average for larval tachyines (as in Fig. 59); lateral side of ninth abdominal tergum with secondary seta at middle.

Monophyly and phylogenetic relationships. Monophyly of this taxon based on larval characters is uncertain since we did not find any autapomorphic feature. The studied larvae of this genus share with those of Tachys a single synapomorphic character state, namely pore $\mathrm{MX}_{\mathrm{c}}$ on ventral surface of stipes removed proximad and located at middle of stipes instead of being located at distal quarter. Only two specimens of two species are available for study; they are dissimilar and each of them possesses some unique apomorphic characters. Relationship of Polyderis will remain uncertain until more larvae are available for study. See also remarks under each species treated.

Geographical distribution and diversity. The genus Polyderis has not been recently revised, but Erwin (1974a) recognised over 50 species from all zoogeographical regions and oceanic islands.

\section{Polyderis ?rufotestacea (Hayward, 1900)} (Figs 6, 29)

Diagnosis. This species can be distinguished by having the seta $\mathrm{FR}_{9}$ on frontale as short as $\mathrm{FR}_{5}$.
Description. First instar-larvae. HW $=0.19 \mathrm{~mm}$, HL $=0.17 \mathrm{~mm}(\mathbf{n}=1)$. Nasale: Fig. 29 ; seta $\mathrm{FR}_{9}$ as short as $\mathrm{FR}_{5}$; pore $\mathrm{PA}_{\mathrm{b}}$ on parietale present. Second and third instars. Not available.

Material studied. $1 \mathrm{~L}_{1}$ (mounted on slide) reared from adults collected on February 23, 1996, San Pedro River at Charleston, Arizona, USA, D. Maddison (DRM 96001).

Remarks. Larvae of this species are known from a single specimen; additional material is needed to confirm the morphological features.

Polyderis laevis (Say, 1823)

(Figs 20, 30, 52)

Diagnosis. This species can be immediately recognised by the absence of pore $\mathrm{PA}_{b}$ on parietale.

Description. First-instar larvae. Not available. Second and third instars. $\mathrm{HW}=0.18 \mathrm{~mm}, \mathrm{HL}=0.17$ $\mathrm{mm}(\mathrm{n}=1)$ in second instar. Nasale: Fig. 30. Seta FR about 3-4× longer than $\mathrm{FR}_{5}$; pore $\mathrm{PA}_{\mathrm{b}}$ on parietale absent. Third-instar larvae not available.

Material studied. $1 \mathrm{~L}_{2}$ (mounted on slide) reared from adults collected on June 23, 1985, Burlington, Ontario, Canada, D. Maddison (DRM 85014).

Remarks. Like the previous Polyderis species, $P$. laevis is known from a single larval specimen. It has an unusual apomorphic character state: parietale without pore $\mathrm{PA}_{\mathrm{b}}$. The character is unique for the tribe and has been noted only for larvae of Thalassophilus longicornis (Sturm, 1825), a member of the tribe Trechini (Grebennikov, 1996). Additional material is needed to confirm the described characters.

\section{Genus Elaphropus Motschulsky, 1839}

Diagnosis. Studied larvae of this genus possess no remarkable feature which might be used to separate them from those of other genera described; see key to genera.

Description. All instar. Cephalic capsule subcylindrical, parallel-sided (Figs 8, 53); pore $\mathrm{PA}_{\mathrm{b}}$ present distad of level of seta $\mathrm{PA}_{2}$; sensorium on antennomere III large (Fig. 15); terebra without serration; pore $\mathrm{MX}_{\mathrm{c}}$ in distal fourth of ventral surface of stipes; distal seta of group gMX on stipes anteriad of level of seta $\mathrm{MX}_{5}$; pore $\mathrm{PR}_{\mathrm{h}}$ on protergum present (as on Fig. 59); setae $\mathrm{PR}_{13}, \mathrm{ME}_{14}$, and $\mathrm{TE}_{11}$ about $3-5 \times$ longer than proximal diameter of setae $\mathrm{PR}_{12}, \mathrm{ME}_{13}$, and $\mathrm{TE}_{10}$ respectively; seta on claw as short as $1 / 4$ proximal diameter of claw. First instar. Frontal sutures V-shaped posteriad (Figs 7, 8); frontale without egg-bursters but with microspines at base; parietale with microspines laterad of seta $\mathrm{PA}_{3}$; seta $\mathrm{FR}_{4}$ about $3-5 \times$ longer than diameter of seta $\mathrm{FR}_{2}$; seta $\mathrm{FR}_{6}$ closer to $\mathrm{FR}_{\mathrm{e}}$ than to $\mathrm{FR}_{f}$; seta $\mathrm{FR}_{9}$ normal, about $3-5 \times$ longer than $\mathrm{FR}_{5}$; dorsal surface of mandible near pore $\mathrm{MN}_{\mathrm{b}}$ with microspines; group gMX on stipes with 5 setae; second galeomere about $3 \times$ longer than first. Second and third instars. Ocular groove absent (Fig. 53); group gMX on stipes with 6 setae (Fig. 47); galea longer than two proximal maxillary palpomeres combined; terga with number of secondary setae average for larval tachyines 
(Fig. 59); lateral side of ninth abdominal tergum with secondary seta at middle (Fig. 59).

Monophyly and phylogenetic relationships. Studied larvae of this genus share no synapomorphic feature; consequently monophyly of this taxon is uncertain. There are also no apomorphies shared with other tachyines or xystosomines that would indicate the sister group of Elaph ropus.

Geographical distribution and diversity. This widely distributed genus is accepted in the present paper according to Erwin's (1974a) limits; since the genus was never entirely revised, it is not possible to provide the precise number of species. Erwin (1974a) pointed out that the group's greatest diversity is in the Oriental Region and in Africa. Recently Baehr (1987) revised the Australian fauna of Elaphropus and listed 23 species of the subgenus Elaphropus and one of the subgenus Sphaerotachys (the latter taxon is regarded in the current work as a separate genus).

\section{Elaphropus diabrachys (Kolenati, 1845)}

(Figs 7, 15, 31, 32, 47, 53, 59)

Diagnosis. Larvae of this species can be separated from those of $E$. tripunctatus by the length of setae $\mathrm{FR}_{3}$ and $\mathrm{FR}_{4}$ on frontale, which are $2 \times$ longer than seta $\mathrm{FR}_{5}$.

Description. First-instar larvae. $\mathrm{HW}=0.26-0.27$ $\mathrm{mm}, \mathrm{HL}=0.23-0.25 \mathrm{~mm}(\mathrm{n}=4)$. Nasale: Fig. 31 . Setae $F_{3}$ and $F R_{4}$ about $2 \times$ longer than $F_{5}$. Second and third instars. $\mathrm{HW}=0.29 \mathrm{~mm}$, $\mathrm{HL}=0.30 \mathrm{~mm}(\mathrm{n}=1)$ in second instar and $\mathrm{HW}=0.43-0.45 \mathrm{~mm}, \mathrm{HL}=0.46-0.48 \mathrm{~mm}(\mathrm{n}$ $=2$ ) in third instar. Nasale: Fig. 32

Material studied. $4 \mathrm{~L}_{1}, 1 \mathrm{~L}_{2}, 2 \mathrm{~L}_{3}$ (mounted on slide) reared from adults collected on April 12, 1995, Nikel, Belaya River, western part of Caucasus Range, Russia, V. Grebennikov (VVG). Additional material reared but not studied in detail includes $7 \mathrm{~L}_{1}, 3 \mathrm{~L}_{2}, 5 \mathrm{~L}_{3}$ from the same place.

\section{Elaphropus tripunctatus (Say, 1830)}

(Figs 8, 33)

Diagnosis. Larvae of this species can be distinguished from those of $E$. diabrachys by the length of setae $\mathrm{FR}_{3}$ and $\mathrm{FR}_{4}$ on frontale being about as long as seta $\mathrm{FR}_{5}$.

Description. First instar-larvae. $\mathrm{HW}=0.25 \mathrm{~mm}$, HL $=0.24 \mathrm{~mm}(\mathrm{n}=1)$. Nasale: Fig. 33. Setae $\mathrm{FR}_{3}$ and $\mathrm{FR}_{4}$ about as long as $\mathrm{FR}_{5}$. Second and third instars. $\mathrm{HW}=$ $0.35 \mathrm{~mm}, \mathrm{HL}=0.33 \mathrm{~mm}(\mathrm{n}=1)$ in second instar. Thirdinstar larvae not available.

Material studied. $1 \mathrm{~L}_{1}, 1 \mathrm{~L}_{2}$ (mounted on slide) reared from adults collected on May 6, 1986, Burlington, Ontario, Canada, D. Maddison (DRM 86011).

\section{Genus Sphaerotachys G. Müller, 1926}

Diagnosis. Larvae of this genus can be recognised by the presence of numerous (about 15) small and equal teeth on cutting edge of terebra (Figs 9, 54). Larvae of the genera Paratachys and Porotachys also have teeth on terebra, but they are less numerous (not more than 10), and the shape of the teeth is different (Figs 10, 11, 55, 56).
Description. All instars. Cephalic capsule subcylindrical, parallel-sided (Figs 9, 54); pore $\mathrm{PA}_{\mathrm{b}}$ present distad of level of seta $\mathrm{PA}_{2}$; sensorium on antennomere III large; terebra with serration; pore $\mathrm{MX}_{\mathrm{c}}$ in distal fourth of ventral surface of stipes; distal seta of group gMX on stipes anteriad of level of seta $\mathrm{MX}_{5}$ (Fig. 43); pore $\mathrm{PR}_{\mathrm{h}}$ on protergum present; setae $\mathrm{PR}_{13}, \mathrm{ME}_{14}$, and $\mathrm{TE}_{11}$ about $3-5 \times$ longer than proximal diameter of setae $\mathrm{PR}_{12}, \mathrm{ME}_{13}$, and $\mathrm{TE}_{10}$ respectively; seta on claw as short as $1 / 4$ of proximal diameter of claw. First instar. Frontal sutures V-shaped posteriad (Fig. 9); frontale without egg-bursters but with microspines at base; parietale with microspines laterad of seta $\mathrm{PA}_{3}$; seta $\mathrm{FR}_{4}$ about $3-5 \times$ longer than diameter of seta $\mathrm{FR}_{2}$; seta $\mathrm{FR}_{6}$ closer to $\mathrm{FR}_{\mathrm{e}}$ than to $\mathrm{FR}_{\mathrm{f}}$; seta $\mathrm{FR}_{9}$ normal, about $3-5 \times$ longer than $\mathrm{FR}_{5}$; dorsal surface of mandible near pore $\mathrm{MN}_{\mathrm{b}}$ with microspines; group $\mathrm{gMX}$ on stipes with 5 setae; second galeomere about $3 \times$ longer than first. Second and third instars. Ocular groove absent (Fig. 54); group gMX on stipes with 6 setae; galea longer than two proximal maxillary palpomeres combined; terga with number of secondary setae average for larval tachyines (Fig. 59); lateral side of ninth abdominal tergum with secondary seta at middle.

Monophyly and phylogenetic relationships. Larvae of the single species studied possess equal serration along the cutting edge of terebra which we consider as an apomorphic character state. We believe that teeth appear independently within the subtribe for Sphaerotachys on one hand and Porotachys + Paratachys on the other because of the different shape and number of teeth. Relationship of the genus is obscure since no synapomorphic character state has been found.

Remarks. Based on adult morphology, Sphaerotachys is closely related to the genus Elaphropus and is regarded by some authors as a subgenus (Baehr, 1987; Kryzhanovskij et al., 1995) or even as a synonym (Erwin, 1974a) of the latter.

Geographical distribution and diversity. Kryzhanovskij (1983) pointed out that the genus has a few widespread species in Australia and Old World. More precise information is absent since the genus has never been revised.

\section{Sphaerotachys haemorrhoidalis (Ponza, 1805) \\ (Figs 9, 34, 35, 43, 54)}

Diagnosis. See Diagnosis section of the genus.

Description. First-instar larvae. $\mathrm{HW}=0.21-0.22$ $\mathrm{mm}, \mathrm{HL}=0.20-0.21 \mathrm{~mm}(\mathrm{n}=1)$. Nasale: Fig. 34 . Second and third instars. $\mathrm{HW}=0.28 \mathrm{~mm}, \mathrm{HL}=0.29$ $\mathrm{mm}(\mathrm{n}=1)$ in second instar and $\mathrm{HW}=0.40-0.42 \mathrm{~mm}$, $\mathrm{HL}=0.44-0.45 \mathrm{~mm}(\mathbf{n}=2)$ in third instar. Nasale: Fig. 35 .

Material studied. $2 \mathrm{~L}_{1}, 1 \mathrm{~L}_{2}, 2 \mathrm{~L}_{3}$ (mounted on slide) reared from adults collected on April 16, 1996, Sekisiab River, northern slope of Kopet-Dag Range, Turkmenia, V. Grebennikov (VVG). Additional material reared but not studied in detail includes $4 \mathrm{~L}_{1}, 1 \mathrm{~L}_{2}, 4 \mathrm{~L}_{3}$ from the same place. 


\section{Genus Paratachys Casey, 1918}

Diagnosis. Larvae of all instars of this genus (as well as Porotachys) can be recognised by having the terebra with some large teeth near the retinaculum and much smaller serrations or smooth cutting edge distally (Figs 10, 11, $55,56)$. Larvae of the genus Sphaerotachys also have teeth on the terebra (Figs 9, 54), but their shape and number differ from those of Paratachys and Porotachys. For separation of these two genera see key.

Description. All instars. Cephalic capsule subcylindrical (Figs 10, 55), parallel-sided; pore $\mathrm{PA}_{b}$ present distad of level of seta $\mathrm{PA}_{2}$; sensorium on antennomere III large (Fig. 16); terebra with serration; pore $\mathrm{MX}_{\mathrm{c}}$ in distal fourth of ventral surface of stipes; distal seta of group gMX on stipes anteriad of level of seta $\mathrm{MX}_{5}$; pore $\mathrm{PR}_{\mathrm{h}}$ on protergum present; setae $\mathrm{PR}_{13}, \mathrm{ME}_{14}$, and $\mathrm{TE}_{11}$ about 3-5x longer than proximal diameter of setae $\mathrm{PR}_{12}, \mathrm{ME}_{13}$, and $\mathrm{TE}_{10}$ respectively; seta on claw as short as $1 / 4$ of proximal diameter of claw. First instar. Frontal sutures V-shaped posteriorly (Fig. 10); frontale without egg-bursters but with microspines at base and near pore $\mathrm{FR}_{\mathrm{b}}$; parietale smooth, without microspines laterad of seta $\mathrm{PA}_{3}$; seta $\mathrm{FR}$ about 3-5× longer than diameter of seta $\mathrm{FR}_{2}$; seta $\mathrm{FR}_{6}$ closer to $F R_{\mathrm{e}}$ than to $\mathrm{FR}_{\mathrm{f}}$; seta $\mathrm{FR}_{9}$ normal, about 3-5x longer than $\mathrm{FR}_{5}$; dorsal surface of mandible with microspines near pore $\mathrm{MN}_{\mathrm{b}}$; group gMX on stipes with 5 setae; second galeomere about $3 \times$ longer than first. Second and third instars. Ocular groove absent (Fig. 55); group gMX on stipes with 6 setae; terga with number of secondary setae average for larval tachyines (as on Fig. 59); galea longer than two proximal maxillary palpomeres combined; lateral side of ninth abdominal tergum with secondary seta at middle (as on Fig. 59).

Monophyly and phylogenetic relationships. Larvae of the sole species studied exhibit no apomorphies. They share with those of the genus Porotachys a single apomorphic character: the presence of some large teeth at the base of the cutting edge of the terebra.

Geographical distribution and diversity. Erwin (1974a) indicated that the widespread genus Paratachys includes about 300 species in the New World alone, and that most of them are undescribed.

\section{Paratachys bistriatus (Duftschmid, 1812)}

(Figs 10, 16, 36, 37, 55)

Diagnosis. See Diagnosis section of the genus.

Description. First instar larvae. $\mathrm{HW}=0.20 \mathrm{~mm}$, HL $=0.20 \mathrm{~mm}(\mathbf{n}=1)$. Nasale: Fig. 36 . Second and third instars. $\mathrm{HW}=0.26 \mathrm{~mm}, \mathrm{HL}=0.28 \mathrm{~mm}(\mathrm{n}=1)$ in second instar and $\mathrm{HW}=0.36 \mathrm{~mm}, \mathrm{HL}=0.40 \mathrm{~mm}(\mathrm{n}=1)$ in third instar. Nasale: Fig. 37.

Material studied. $2 \mathrm{~L}_{1}, 1 \mathrm{~L}_{2}, 1 \mathrm{~L}_{3}$ (mounted on slide) reared from adults collected on May 25, 1995, Sarepta, Volgograd, Russia, V. Grebennikov (VVG). Additional material reared but not studied in detail includes $9 \mathrm{~L}_{1}$ from the same place; $1 \mathrm{~L}_{1}, 1 \mathrm{~L}_{2}$, $1 L_{3}$ from adults collected on April 20, 1995, Pchelovodnaya, Rostov distr., Russia, V. Grebennikov (VVG); and $2 \mathrm{~L}_{1}, 2 \mathrm{~L}_{3}$ from adults collected on April 5, 1995, Tanais, Rostov distr., Russia, V. Grebennikov (VVG).

\section{Genus Porotachys Netolitzky, 1914}

Diagnosis. See Diagnosis section for the genus Paratachys.

Description. All instars. Cephalic capsule subcylindrical, parallel-sided (Figs 11,56); pore $\mathrm{PA}_{\mathrm{b}}$ present distad of level of seta $\mathrm{PA}_{2}$; sensorium on antennomere III large (Fig. 17); terebra with serration; pore $\mathrm{MX}_{\mathrm{c}}$ in distal fourth of ventral surface of stipes; distal seta of group $\mathrm{gMX}$ on stipes anteriad of level of seta $\mathrm{MX}_{5}$ (Fig. 44); pore $\mathrm{PR}_{\mathrm{h}}$ on protergum present; setae $\mathrm{PR}_{13}, \mathrm{ME}_{14}$, and $\mathrm{TE}_{11}$ about $3-5 \times$ longer than proximal diameter of setae $\mathrm{PR}_{12}, \mathrm{ME}_{13}$, and $\mathrm{TE}_{10}$ respectively; seta on claw as short as $1 / 4$ of proximal diameter of claw. First instar. Frontal sutures V-shaped posteriorly (Fig. 11); frontale without egg-bursters but with microspines at base and near pore $\mathrm{FR}_{\mathrm{b}}$; parietale with microspines laterad of seta $\mathrm{PA}_{3}$; seta $\mathrm{FR}_{4}$ about 3-5× longer than diameter of seta $\mathrm{FR}_{2}$; seta $\mathrm{FR}_{6}$ closer to $\mathrm{FR}_{\mathrm{e}}$ than to $\mathrm{FR}_{\mathrm{f}}$; seta $\mathrm{FR}_{9}$ normal, about 3-5× longer than $\mathrm{FR}_{5}$; dorsal surface of mandible near pore $\mathrm{MN}_{\mathrm{b}}$ with microspines; group gMX on stipes with 5 setae; second galeomere about $3 \times$ longer than first (Fig. 44). Second and third instars. Ocular groove absent (Fig. 56); group gMX on stipes with 6 setae; galea longer than two proximal maxillary palpomeres combined (Fig. 48); terga with number of secondary setae average for larval tachyines (Fig. 60); lateral side of ninth abdominal tergum with secondary seta at middle (Fig. 60).

Phylogenetic relationships. The presence of large teeth at the base of the cutting edge of the terebra indicates that the genus Porotachys is related to the genus Paratachys.

Geographical distribution and diversity. This genus includes a single described species, Porotachys bisulcatus, which is widely distributed in the western part of Palaearctic Region and was accidentally introduced in North America (Kryzhanovskij, 1983). Erwin (1974a: 126) mentioned a second, apparently undescribed species of this genus from the Oriental Region.

Porotachys bisulcatus (Nicolai, 1822)

(Figs 11, 17, 38, 39, 48, 56, 60)

Diagnosis. See Diagnosis section of the genus.

Description. First-instar larvae. $\mathrm{HW}=0.26-0.28$ $\mathrm{mm}, \mathrm{HL}=0.24-0.25 \mathrm{~mm}(\mathrm{n}=4)$. Nasale: Fig. 38 . Second and third instars. $\mathrm{HW}=0.31 \mathrm{~mm}, \mathrm{HL}=0.33$ $\mathrm{mm}(\mathrm{n}=1)$ for second instar and $\mathrm{HW}=0.42-0.44 \mathrm{~mm}$, $\mathrm{HL}=0.44-0.45 \mathrm{~mm}(\mathbf{n}=2)$ for third instar. Nasale: Fig. 39.

Material studied. $4 \mathrm{~L}_{1}, 1 \mathrm{~L}_{2}, 2 \mathrm{~L}_{3}$ (mounted on slide) reared from adults collected on April 14, 1995, Dede River, Tuapse region, southwestern part of Caucasus Range, Russia, V. Grebennikov (VVG). Additional material reared but not studied in detail includes $4 \mathrm{~L}_{1}, 4 \mathrm{~L}_{2}, 7 \mathrm{~L}_{3}$ from the same place.

\section{CONCLUDING REMARKS}

Larvae of Mioptachys flavicauda (the only larvae known to date of the subtribe Xystosomina) have many apomorphic features shared with those of the subtribe Tachyina (they were noted above in the discussion of monophyly of Xystosomina + Tachyina). There is, how- 
ever, no apomorphic character state to support the monophyly of the subtribe Tachyina exclusive of Xystosomina. Since larvae of only a single Xystosomina taxon are known, we have no evidence about the monophyly of that subtribe as well. Under these circumstances it is impossible to separate both cited taxa for phylogenetic discussion because none has clearly supported monophyly based on larval morphology.

Based on at least six synapomorphic character states the subtribes Tachyina and Xystosomina appear to form a monophyletic group. On the other hand, no synapomorphic feature has been discovered to propose a sister group to the Tachyina + Xystosomina within the supertribe Trechitae in general and the tribe Bembidini in particular. Tachyina and Xystosomina could be regarded as members of a separate tribe Tachyini following Kryzhanovskij (1983), but this conclusion requires a more complete cladistic analysis, which is not currently possible with larvae of many Trechitae taxa remaining unknown.

The genera Tachyta and Mioptachys are rather similar in larval morphology. Nevertheless, we believe that all shared similarities are convergent characters or at least of unknown phylogenetic value, and, consequently, do not reflect the true relationship between the genera treated.

Study of larvae supports the view that Paratachys is a separate genus, not a subgenus of Tachys (contrary to the opinion expressed in Kryzhanovskij, 1983, and Kryzhanovskij et al., 1995). In fact, based on larval morphology, these two genera are not even sister groups, with Polyderis being more closely related to Tachys, and Porotachys being more closely related to Paratachys.

ACKNOWLEDGEMENTS. E.V. Komarov (Volgograd, Russia) shared the information about some Tachyina species in southern Russia. I.A. Belousov (Sankt Petersburg, Russia) checked the identification of some Palaearctic species. M.L. Luff (Newcastle upon Tyne, UK) and B.P. Moore (Canberra, Australia) provided some undescribed Trechitae larvae for comparative study. The senior author thanks his research supervisors I.Kh. Sharova (Moscow, Russia) and Y. Bousquet (Ottawa, Canada) for moral support; the last person also critically read the manuscript. E.A Moskvitina and A.D. Lipkovich (Rostov-on-Don, Russia) provided the senior author with working facilities. T.L. Erwin (Washington, D.C., USA) and two anonymous referees commented on the early draft of the paper. We sincerely thank all these people for their help.

\section{REFERENCES}

ARndT E. 1991: Familie Carabidae. In Klausnitzer B. (ed.): Die Larven der Käfer Mitteleuropas. Vol. 1: Adephaga. Goecke \& Evers, Krefeld, pp. 45-141.

BAEHR M. 1986: Review of the Australian species of genus Tachyta Kirby (Coleoptera: Carabidae: Bembidinae). Entomofauna 7: 305-313.

BAEHR M. 1987: A review of the Australian Tachyine beetles of the subgenera Tachyura Motschulsky and Sphaerotachys Müller with special regard to the tropical fauna (Insecta: Coleoptera: Carabidae: Bembidiinae). Spixiana 10: 225-269.

BAEHR M. 1989: A new species of the Tachys ectromoidesgroup from western Australia (Coleoptera: Carabidae: Bembidiinae). Spixiana 12: 179-283.
BAEHR M. 1990: Revision of the Australian ground-beetle genus Tasmanitachoides Erwin (Insecta: Coleoptera: Carabidae: Bembidiinae), with special regard to the tropical species. Invertebr. Taxon. 4: 867-894.

BAEHR M. 1995: Revision of Philipis (Coleoptera: Carabidae: Bembidiinae), a genus of arboreal tachyine beetles from the rainforests of Eastern Australia: Taxonomy, phylogeny and biogeography. Mem. Queensl. Mus. 38: 315-381.

Bousquet Y. 1985: Morphologie comparée des larves de Pterostichini (Coleptera: Carabidae): Description et tables de détermination des espèces du Nord-Est de l'Amérique du Nord. Naturaliste Can. 122: 191-251.

Bousquet Y. \& Goulet H. 1984: Notation of primary setae and pores on larvae of Carabidae (Coleoptera: Adephaga). Can. J. Zool. 62: 573-588.

Bousquet Y. \& Grebennikov V.V. 1999: Platypatrobus lacustris Darlington (Coleoptera: Carabidae): adult and larval morphology. Fabreries 24: 1-13.

Cerruti M. 1939: Larva del Tachys parvulus Dej. (Coleoptera: Carabidae). Mem. Soc. Entomol. Ital. 17: 121-124.

EMDEN F.I. VAN 1942: A key to the genera of larval Carabidae (Coleoptera). Trans. R. Entomol. Soc. Lond. 92: 1-99.

ERwIN T.L. 1973: Studies of the subtribe Tachyina (Coleoptera: Carabidae: Bembidiini). Part 1: A Revision of the Neotropical genus Xystosomus Schaum. Smithson. Contr. Zool. No. 140, $39 \mathrm{pp}$.

ERwIN T.L. 1974a: Studies of the subtribe Tachyina (Coleoptera: Carabidae: Bembidiini), Supplement A: Lectotype designation for New World species, two new genera, and notes on generic concept. Proc. Entomol. Soc. Wash. 76: 123-155.

ERWIN T.L. 1974b: Studies of the subtribe Tachyina (Coleoptera: Carabidae: Bembidiini), Part 2: A Revision of the New World - Australian genus Pericompsus LeConte. Smithson. Contr. Zool. No. 162, 96 pp.

ERwIN T.L. 1975: Studies of the subtribe Tachyina (Coleoptera: Carabidae: Bembidiini), Part 3: Systematics, Phylogeny, and Zoogeography of the genus Tachyta Kirby. Smithson. Contr. Zool. No. 208, 68 pp.

ERWIN T.L. 1978: Studies of the subtribe Tachyina (Coleoptera: Carabidae: Bembidiini), Supplement C: Discovery of the sister group of Mioptachys Bates, in the Amason Basin - Inpa psydroides a new genus and species. Coleopt. Bull. 32: $29-36$.

ERWIN T.L. 1982: Small terrestrial ground-beetles of Central America (Carabidae: Bembidiina and Anillina). Proc. Calif. Acad. Sci. 42(19): 455-496.

ERWIN T.L. 1994: Arboreal beetles of tropical forest: The Xystosomi group, subtribe Xystosomina (Coleoptera: Carabidae: Bembidiini). Part 1. Character analysis, taxonomy, and distribution. Can. Entomol. 126: 549-666.

GARDNER J.C.M. 1938: Immature stages of Indian Coleoptera (23), Carabidae. Indian For. Rec. 3: 149-157.

Goulet H. 1983: The genera of Holarctic Elaphrini and species of Elaphrus Fabricius (Coleoptera: Carabidae): Classification, phylogeny and zoogeography. Quaest. Entomol. 19: 219-482.

GREBENNIKov V.V. 1996: Description of the first instar larva of Thalassophilus longicornis (Coleoptera: Carabidae: Trechodina). Acta Soc. Zool. Bohem. 60: 373-379.

GrebenntKov V.V. \& LuFF M.L. 1998: Description of larvae of Aepopsis robini (Coleoptera: Carabidae: Trechini). Eur. J. Entomol. 95: 623-627.

KIRK V.M. 1972: Identification of ground beetle larvae found in cropland in South Dakota. Ann. Entomol. Soc. Am. 65: $1349-1356$. 
KRYZHANOVSKIJ O.L. 1976: An attempt of a revised classification of the family Carabidae (Coleoptera). Entomol. Obozr. 55: 80-91 (in Russian).

KRYZHANOVSKIJ O.L. 1983: The beetles of the suborder Adephaga: families Rhysodidae, Trachypachidae, Carabidae (introduction and a review of the USSR fauna). Fauna USSR I(2). Nauka, Leningrad, 341 pp. (in Russian).

Kryzhanovski O.L., Belousov I.A., Kabak I.I., Kataev B.M., Makarov K.V. \& Shilenkov V.G. 1995: A checklist of the ground-beetles of Russia and adjacent lands (Insecta: Coleoptera: Carabidae). Pensoft Publishers, Sofia-Moscow, 271 pp.

LARSSON S.G. 1968: Lobebillernes larver. In Hansen V. (ed) Biller XXIV. Sandspringere og lobebiller (Cicindelidae og Carabidae) [Larvae of Ground Beetles. Volume XXIV. Tiger Beetles and Ground Beetles (Cicindelidae and Carabidae)]. Danmarks Fauna 76. G.E.C. Gads, København, pp. 282-433.

LufF M.L. 1993: The Carabidae (Coleoptera) larvae of Fennoscandia and Denmark. Fauna Entomologica Scandinavica 27. E.J. Brill, Leiden, New York, Köln, 187 pp.

MaKarov K.V. 1996: Patterns of chaetome modifications in ground-beetle larvae (Coleoptera: Carabidae). Acta Soc. Zool. Bohem. 60: 391-418.

MadDison D.R. 1993: Systematics of the Holarctic beetle subgenus Bracteon and related Bembidion (Coleoptera: Carabidae). Bull. Mus. Compar. Zool. 153: 143-299.

Maddison D.R., Baker M.D. \& Ober K.A. 1999: Phylogeny of carabid beetles as inferred from $18 \mathrm{~S}$ ribosomal DNA (Coleoptera: Carabidae). Syst. Entomol. 24: 103-138.

NiritsKY N.B. 1976: Morphology of beetles with predatory larvae, which occur together with bark-beetles in northwest Cau- casus. In Mamaev B.M. (ed): Evolutionary Morphology of Insect Larvae. Nauka, Moscow, pp. 175-201 (in Russian).

Perris E. 1862: Histoire des insectes du pin maritime. Supplément aux coléoptères et rectifications. Ann. Soc. Entomol. Fr. (Sér. 4) 2: 173-243, pls 5-6.

Sharova I.KH. 1958: The larvae of Carabidae beneficial and noxious to agriculture. Uchen. Zap. Mosk. Gos. Pedag. Inst. 124: 1-165 (in Russian).

SHAROVA I.KH. 1964: Family Carabidae. In Gilyarov M.S. (ed.): Opredelitel' obitayushchikh v pochve lichinok nasekomykh [Key to Soil-Dwelling Insect Larvae]. Nauka, Moscow, pp. 112-195 (in Russian).

SteBbing E.P. 1914: Indian Forest Insects of Economic Importance. Coleoptera. Eyre and Spottiswoode, London, XvI +648 pp.

THOMPSON R.T. 1979: Larvae of North American Carabidae with a key to the tribes. In Erwin T.L., Ball G.E. \& Whitehead D.R.W. (eds): Carabid Beetles: Their Evolution, Natural History, and Classification. Proceedings of the First International Symposium of Carabidology. Junk Publishers, The Hague, pp. 209-291.

Xambeau V. 1894: Moeurs et métamorphoses d'insectes. 5e mémoire. Ann. Soc. Linn. Lyon 41: 107-156.

Zamotallov A.S. 1994: The carabid genus Deltomerus Motschulsky, 1850 of the Caucasus. 3. Description of new species and preliminary diagnosis of larvae (Coleoptera: Carabidae). Zoosystem. Ross. 3(1): 75-95.

Received October 12, 1998; accepted March 28, 2000 